\title{
Overlapping and Distinct Actions of the Neurotrophins BDNF, NT-3, and NT-4/5 on Cultured Dopaminergic and GABAergic Neurons of the Ventral Mesencephalon
}

\author{
Carolyn Hyman, Melissa Juhasz, Carl Jackson, Paul Wright, Nancy Y. Ip, and Ronald M. Lindsay \\ Regeneron Pharmaceuticals, Inc., Tarrytown, New York 10591
}

The neurotrophins brain-derived neurotrophic factor (BDNF), neurotrophin-3 (NT-3), and neurotrophin-4/5 (NT-4/5) were compared for their effects in promoting the survival and/or regulation of expression of phenotypic markers of dopaminergic and GABAergic neurons in cultures derived from embryonic rat ventral mesencephalon. Dopaminergic neuron number and phenotypic expression were monitored by tyrosine hydroxylase (TH) immunocytochemistry, and measurement of high-affinity dopamine uptake activity and dopamine content, respectively. High-affinity GABA uptake, glutamic acid decarboxylase (GAD) activity, and endogenous GABA content were used to detect GABAergic neurons. Seven days of treatment with either BDNF or NT-3 resulted in dose-dependent increases in the number of THpositive neurons, with maximal responses of 3-fold and 2.3fold, respectively. Dopamine uptake activity and dopamine content were similarly increased. The effects of BDNF and NT-3 on dopamine uptake activity showed no additivity. NT$4 / 5$ treatment elicited the greatest increase $(7$-fold) in the number of TH-positive neurons, as well as a 2.6-fold increase in dopamine content. In marked contrast to BDNF or NT-3, NT-4/5 had no effect on dopamine uptake capacity. BDNF, NT-3, or NT-4/5 also produced dose-dependent elevations of 2-3-fold in GABA uptake activity. These effects were not additive. GAD activity was increased by BDNF (1.8-fold) and NT-3 (threefold) treatment, but not by NT-4/5, whereas GABA content was increased to a similar extent by all three neurotrophins. NGF had no effect on any of the parameters measured in this study. Northern analyses indicated that the mRNAs encoding TrkB and TrkC, the functional high-affinity receptors for BDNF and NT-4/5, and NT-3, respectively, are expressed in the substantia nigra of adult rat brain, as well as in cultures of developing ventral mesencephalon. Taken together, our results indicate that BDNF and NT-3 have broadly similar effects in promoting the survival and differentiated phenotype of both dopaminergic and GABAergic neurons of the developing substantia nigra. Although BDNF

\footnotetext{
Received Jan. 19, 1993; revised July 8, 1993; accepted July 13, 1993.

We gratefully acknowledge the assistance of Carolyn Boylan with neurochemical assays. We thank Dr. James Miller of Amgen, Thousand Oaks, CA, for the BDNF and NT-3 used in this study. The NT-4/5 was kindly supplied by Drs. Jim Fand and Nancy Tobkes. We also greatly appreciate the efforts of staff in the RNA center at Regeneron who helped generate the in situ localization maps of $t r k B$ and trkC in adult brain. We also thank Susan Davenport, Paula Stone, and Rhonda Littlefair for assistance with the preparation of the manuscript.

Cortespondence should be addressed to Carolyn Hyman, Regeneron Pharmaceuticals, Inc., 777 Old Saw Mill River Road. Tarrytown, NY 10591.

Copyright (c) 1994 Society for Neuroscience $0270-6474 / 94 / 140335-13 \$ 05.00 / 0$
}

and NT-4/5 are thought to act through the same high-affinity receptor, TrkB, it is evident that these two neurotrophins have distinct as well as overlapping actions toward mesencephalic dopaminergic or GABAergic neurons.

[Key words: neurotrophin, dopaminergic, GABAergic, tyrosine hydroxylase, glutamic acid decarboxylase, substantia nigral

NGF, the best-characterized neurotrophic factor, supports survival, growth, and differentiation of cultured sympathetic and neural crest-derived sensory neurons in the PNS (Bradshaw, 1978; Thoenen and Barde, 1980; Thoenen et al., 1987), as well as basal forebrain cholinergic neurons of the CNS (Hartikka and Hefti, 1988; Hatanaka et al., 1988). It is now evident that NGF is a member of a family of structurally and functionally related molecules, termed the neurotrophins. This family includes brainderived neurotrophic factor (BDNF) (Barde et al., 1982; Leibröck et al., 1988), neurotrophin-3 (NT-3) (Ernfors et al., 1990a; Hohn et al., 1990; Maisonpierre et al., 1990a; Rosenthal et al., 1990), and neurotrophin-4/5 (NT-4/5; alternatively known as NT-4 or NT-5) (Berkemeier et al., 1991; Hallböök et al., 1991; Ip et al., 1992). Within the PNS, BDNF and NT-3 have been shown to be survival factors for neural crest- and neural placode-derived sensory neurons (Lindsay et al., 1985; Davies et al., 1986; Hofer and Barde, 1988; Hohn et al., 1990; Maisonpierre et al., 1990a), with little or no effect on sympathetic neurons. In contrast to a very limited distribution of NGF. responsive neurons in the brain, as indicated by both tissue culture and in vivo studies, the widespread CNS distribution of high-affinity receptors for BDNF and NT-3 (TrkB and TrkC, respectively) suggests that many populations of CNS neurons are potentially responsive to BDNF and/or NT-3. Recent tissue culture studies have indicated that both septal cholinergic neurons and nigral dopaminergic neurons are responsive to BDNF (Alderson et al., 1990; Hyman et al., 1991; Knüsel et al., 1991). In contrast to well-established trophic effects on septal cholinergic neurons (Hartikka and Hefti, 1988; Hatanaka et al., 1988), NGF appears to be without effect on nigral dopaminergic neurons (DalToso et al., 1988; Knüsel et al., 1990, 1991; Spina et al., 1992), and currently there are no reports of effects of NGF on nigral GABAergic neurons.

Responsiveness to neurotrophins in vitro or in vivo has been shown to correlate well with the capacity for specific, receptormediated retrograde axonal transport. This has been particularly well established for NGF (Hendry et al., 1974; Stöckel et al., 1975; Johnson et al., 1978; Seiler and Schwab, 1984), where the specificity of retrograde transport of NGF in adult PNS agrees 
well with its neuronal specificity toward developing PNS neurons in vitro (Levi-Montalcini and Angeletti, 1968; Thoenen and Barde, 1980; Lindsay, 1988). In addition, the demonstration of selective retrograde transport of NGF in the CNS has proven to be predictive of neuronal populations that respond to this neurotrophin (Schwab et al., 1979; Seiler and Schwab, 1984). More recently, BDNF, NT-3, and NGF have been shown to have unique patterns of retrograde axonal transport in both peripheral and central neurons (DiStefano et al., 1992), patterns that correlate to their known in vitro and in vivo specificities. For example, specific retrograde transport of radiolabeled NGF and BDNF to the medial septum and diagonal band of Broca following intrahippocampal injections was in agreement with observed overlapping effects of these two neurotrophins on cultured septal cholinergic neurons (Alderson et al., 1990; Knüsel et al., 1991). Similarly, in agreement with in vitro findings, receptor-mediated retrograde transport to the substantia nigra (s. nigra) was observed after intrastriatal injection of either BDNF or NT-3, but not NGF, in adult rat brain (Wiegand et al., 1992). In addition, the demonstration of a high level of NT-3 receptors in adult rat striatum (Altar et al., 1993) may be indicative of a receptor-mediated nature of this phenomenon.

The genes encoding NGF, BDNF, and NT-3 are expressed in many regions of adult rat brain. Northern analysis and in situ hybridization studies have shown that these three neurotrophins are expressed at particularly high levels in the hippocampal formation (Ernfors et al., 1990b; Maisonpierre et al., 1990b). Both within the hippocampus and other brain regions, however, Northern analysis has revealed striking differences in the temporal patterns of expression of NGF, BDNF, and NT-3 mRNA. NT-3 mRNA appears to be most highly expressed early in development, at stages associated with ongoing neurogenesis, whereas NGF and, to an even grcatcr extent, BDNF mRNA expression appear to be most abundant in adult brain. With regard to the nigrostriatal dopamine (DA) system, BDNF mRNA expression has been reported in adult mouse striatum (Hofer et al., 1990), but not in adult rat striatum (Maisonpierre et al., 1990b). More recently, a substantial peak of BDNF mRNA expression has been found in early postnatal rat striatum, at levels that diminish with maturation (R. Ventimiglia, personal communication). BDNF and NT-3 expression have also been detected in the adult rat $s$. nigra and ventral tegmental area (VTA; Gall et al., 1992). Furthermore, during early postnatal development the s. nigra has been shown to express the mRNA encoding BDNF (Friedman et al., 1991). In contrast to the other neurotrophins, levels of expression of NT $-4 / 5$ within the brain are relatively low (Berkemeier et al., 1991). At present, it is unclear whether innervated targets, local support cells, or both are the source of trophic factors that promote survival and differentiation of responsive neuronal populations in the CNS in vivo.

A detailed understanding of the receptors that are involved in eliciting signal transduction by the neurotrophins has begun to emerge. NGF has been known for some time to bind with a transmembrane glycoprotein of approximately $75 \mathrm{kDa}$ with a $K_{u^{\prime}}$ of $10^{9} \mathrm{M}$ (Johnson et al., 1986; Radeke et al., 1987) known as the low-affinity NGF receptor or $\mathrm{p} 75^{\mathrm{INGFR}}$. Both BDNF (Rodriguez-Tébar et al., 1990) and NT-3 (Squinto et al., 1991) have the capacity to compete with NGF for binding to this receptor. However, in order to mediate a biological response, high-affinity binding ( $\left.K_{d}=10^{-11} \mathrm{M}\right)$ is required (Richardson et al., 1986). TrkA, a membrane-spanning receptor tyrosine kinase, the pro- tein product of the trk proto-oncogene, has recently been identified as a functional high-affinity receptor for NGF (Kaplan et al., 1991; Klein et al., 1991a; Meakin and Shooter, 1991; Nebreda et al., 1991). A related molecule, TrkB, has been found to be a functional receptor for BDNF, NT-4/5, and, to a lesser extent, NT-3 (Klein et al., 1991 b; Soppet et al., 1991; Squinto et al., 1991; Ip et al., 1992, 1993). A third family member, TrkC, functions as the preferred high-affinity receptor for NT-3 (Lamballe et al., 1991). One model of the molecular components constituting high-affinity (and thus signal-transducing) binding sites for NGF suggests the involvement of both TrkA and p75 LNGFr (Hempstead et al., 1991; Kaplan et al., 1991). Alternatively, there is considerable in vitro evidence that the Trk proteins alone (perhaps as ligand-induced homodimers) constitute high-affinity, functional neurotrophin receptors (Glass et al., 1991; Klein et al., 1991 a; Squinto et al., 1991; Ibáñez et al., 1992; Jing ct al., 1992).

A recent in situ hybridization study (Merlio et al., 1992) has shown that $\operatorname{trk} B$ and $\operatorname{trk} C$ transcripts are expressed in the $\mathrm{s}$. nigra of the adult rat brain. Given that BDNF and NT-3 are also expressed in this region of the adult brain (Gall et al., 1992), it is possible that neurotrophins may act locally in a paracrine or autocrine fashion. Whereas BDNF exhibits a developmentally regulated pattern of expression in the $s$. nigra, it remains to be determined if TrkB expression in this nucleus follows a similar ontogenic pattern.

In addition to BDNF, many mitogenic growth factors have been reported to affect the survival and/or maturation of nigral dopaminergic neurons, both in vivo and in vitro. Purified factors that have been shown to elevate transmitter-specific differentiation of these cells include basic fibroblast growth factor (bFGF), insulin, insulin-like growth factors I and II, transforming growth factor $\alpha(\mathrm{TGF} \alpha)$, and epidermal growth factor (EGF) (Ferrari et al., 1989, 1990; Knüsel et al., 1990; Casper et al., 1991; Alexi and Hefti, 1993; Beck et al., 1993). The actions of TGF $\alpha$, bFGF, and EGF on dopaminergic neurons have been suggested to be indirectly mediated through a non-neuronal population of dividing cells (Knüsel et al., 1990; Casper et al., 1991; Alexi and Hefti, 1993). Indeed, mesencephalic glial cell lines are known to secrete factors that can support the survival of dopaminergic neurons (Engele et al., 1991), and local nigral support cells have been reported to have the same ability (O'Malley et al., 1991). bFGF has been shown through immunocytochemical staining to be present in both astroglial cells of rat striatum and s. nigra, and nigral dopaminergic neurons (Cintra et al., 1991), suggesting it may play a role in the support of nigral neuron viability. However, the precise physiologic roles of these mitogenic factors, as well as BDNF and NT-3, in development and maintenance of the nervous system remain to be elucidated.

In this report, we describe the effects of the neurotrophins BDNF, NT-3, and NT-4/5 on both dopaminergic and GABAergic neurons present in dissociated cultures of embryonic rat ventral mesencephalon. This culture system contains the anlage of the s. nigra, a midbrain nucleus that is well characterized neuroanatomically, functionally, and neurochemically (Moore and Bloom, 1978). The s. nigra is composed of the pars compacta, which contains predominantly dopaminergic neurons, and the pars reticulata, a region enriched in neurons of a GABAergic phenotype. Identifying neurotrophic factors that effect either of these neuronal populations is of interest due to the focal degeneration of the s. nigra in Parkinson's disease. A variety of phenotypic markers specific to each of these neuronal 
populations were measured after neurotrophin treatment in order to assess their responsiveness. Both BDNF and NT-3 were found to support the survival of dopaminergic and GABAergic neurons in vitro in a manner consistent with utilization of a common pathway. In contrast, NT-4/5 was found to elevate tyrosine hydroxylase (TH) levels without affecting the DA uptake capacity of the cultures. The effects of NT-4/5 on GABAergic neurons were of a smaller magnitude than those observed for BDNF or NT-3, although the nature of the effect was similar. In addition, this report shows by in situ hybridization analysis that TrkB and TrkC are expressed by neurons of the adult rat s. nigra. Finally, and consistent with the observed effects of their cognate ligands, TrkB and TrkC mRNA are shown by Northern blot analysis to be present in the cultures used in this study.

\section{Materials and Methods}

Preparation of ventral mesencephalon cultures from E14 rat brain. Cultures were prepared from the ventral mesencephalon of embryonic day 14 (E14) rat embryos as before (Hyman et al., 1991; Spina et al., 1992). The single-cell suspension obtained following trypsinization and mechanical dissociation of the brain tissue was seeded at a density of $5 \times$ $10^{4}$ cell per $\mathrm{cm}^{2}$ onto $35 \mathrm{~mm}$ dishes that had been precoated with polyL-lysine and merosin (Collaborative Research). After a $4 \mathrm{hr}$ incubation in minimal essential medium supplemented with glutamine ( $2 \mathrm{~mm})$, glucose $(6 \mathrm{mg} / \mathrm{ml})$, penicillin $\mathrm{G}(0.5 \mathrm{U} / \mathrm{ml})$, streptomycin $(5 \mu \mathrm{g} / \mathrm{ml})$, and fetal calf serum (FCS; $7.5 \%$ ) to allow for cell attachment to the substratum, cells were cultured in the presence or absence of trophic factors in a defined medium consisting of F12 and basal Eagle medium (BME; $1: 1, \mathrm{v} / \mathrm{v})$ with N2 supplements as described by Bottenstein and Sato (1979), except that the insulin concentration was reduced to $20 \mathrm{ng} / \mathrm{ml}$, and glutathione was included at $2.5 \mu \mathrm{g} / \mathrm{ml}$.

${ }^{3} H$-dopamine uptake measurement. The measurement of high-aflinity dopamine (DA) uptake activity was carried out according to the method of Tomozawa and Appel (1986). In each treatment group for which high-affinity DA uptake was to be measured, groups of six plates were used. Triplicate cultures were assayed for uptake of ${ }^{3} \mathrm{H}$-dopamine in the presence of $5 \mu \mathrm{M}$ benztropine to determine nonspecific uptake, and three further cultures were assayed under identical conditions except for the omission of benztropine, in order to assess total uptake. Uptake was carried out using ${ }^{3} \mathrm{H}$-dopamine (New England Nuclear; $40 \mathrm{Ci} / \mathrm{mmol}$ ) at a final concentration of $50 \mathrm{~nm}$, for $15 \mathrm{~min}$. Specific uptake was calculated as the difference between total uptake and that uptake which occurred in the presencc of $5 \mu \mathrm{M}$ benztropine. The nonspecific uptake represented between $10-15 \%$ of the total uptake in the cultures.

${ }^{3} \mathrm{H}-\mathrm{GABA}$ uptake measurement. The measurement of high-affinity GABA uptake activity was carried out according to the method of Tomozawa and Appel (1986). Groups of cultures to be tested for highaffinity GABA uptake comprised sets of six culture dishes. Measurement of the total uptake of ${ }^{3} \mathrm{H}-\mathrm{GABA}(50 \mu \mathrm{M})$ was carried out for three cultures in each group; the remaining three cultures were assayed for nonspecific uptake, that which occurs in the presence of $1.0 \mathrm{~mm} \mathrm{L-2,4-diamino-}$ butyric acid. Specific uptake was calculated as the difference between total and nonspecific uptake measurements. Routinely, the nonspecific uptake comprised $5-10 \%$ of the total GABA uptake

Tyrosine hydroxylase immunocytochemical staining. Cultures to be stained for tyrosine hydroxylase ( $\mathrm{TH}$-containing neurons were fixed in $4 \%$ paraformaldchydc and preincubated in phosphate buffer containing $2 \%$ horse serum (Vector Labs, Malverne, PA). After a brief incubation in phosphate buffer containing $0.02 \%$ saponin to permeabilize the cells, cultures were incubated overnight at $4^{\circ} \mathrm{C}$ with mouse anti-rat $\mathrm{TH}$ IgG at $1.0 \mu \mathrm{g} / \mathrm{ml}$ in phosphate buffer containing $1.5 \%$ horse serum and $0.02 \%$ saponin. Following rinses to remove unbound primary antibody, the cells were incubated with horse anti-mouse $\lg G$ conjugated to biotin (Vector Labs, Malverne, PA) at a concentration of $15 \mu \mathrm{g} / \mathrm{ml}$. Specifically bound antibody was subsequently visualized following incubation with avidin-horseradish peroxidase (HRP) (Vector Labs ABC reagent) and diaminobenzidine (DAB).

Glutamic acid decarboxylase immunocytochemical staining. Cultures to be stained for glutamic acid decarboxylase (GAD) were prefixed in a $1: 1$ mixture of $4 \%$ paraformaldehyde and F12/BME $(1: 1, \mathrm{v} / \mathrm{v})$ for 10 min, followed by $30 \mathrm{~min}$ incubation in $4 \%$ paraformaldehyde. Cultures were then incubated in the presence of phosphate buffer containing $4 \%$ goat serum and $0.02 \%$ saponin, after which the cultures were incubated overnight at $4^{\circ} \mathrm{C}$ with goat anti-feline $\mathrm{GAD}_{6}$, antiserum (generously supplied by Dr. A. Tobin, UCLA) at a dilution of 1:7500. Cultures were washed, incubated with goat anti-rabbit IgG at a concentration of 1.5 $\mu \mathrm{g} / \mathrm{ml}$, and specifically bound antibody was detected after binding of avidin-HRP by development using $\mathrm{DAB}$ with $\mathrm{NiSO}_{4}$ intensification (Hancock, 1982).

Measurement of dopamine and GABA content. Dopamine content was determined by an adaptation of the method of Refshauge et al. (1974) and DiPaulo et al. (1982). Cultures were prepared and maintained in vitro for various times, either in the presence or absence of trophic factors. At the end of the culture period, cells were harvested and immediately acidified with $0.4 \mathrm{~N}$ perchlorate containing $0.1 \mathrm{~mm}$ ascorbate and $2.5 \mathrm{ng} / \mathrm{ml}$ dihydroxybenzylamine (an internal standard). Following homogenization and centrifugation to remove precipitated protein, the catecholamines in the extract were absorbed onto alumina (ICN). The samples were then washed extensively, and the catecholamines recovered by extraction from the alumina with $174 \mathrm{~nm}$ acetic acid containing $0.05 \%$ sodium disulfite and $0.025 \%$ EDTA. The protein content of the sample was determined after resuspension of the pelleted precipitate in PBS by the method of Sirith et al. (1985). The catecholamine extracts were injected into the HPLC system (Waters 600E) and separated using a reverse-phase $\mathrm{C}_{18}$ column by isocratic elution in a mobile phase consisting of the following: $0.01 \mathrm{M} \mathrm{NaPO}, 1.0 \mathrm{~mm}$ EDTA, and $0.05 \mathrm{~mm}$ sodium octyl sulfate, $\mathrm{pH}$ 3.0. Quantitation of the various catecholamines was carried out after electrochemical detection (ESA 5100A detector) of the peaks eluted from the HPLC, and the data were normalized to the protein content of the sample. GABA determinations were carried out, after derivatization with $o$-phthalaldehyde, by an HPLC separation using a reverse-phase $\mathrm{C}_{18}$ column in a mobile phase consisting of $25 \%$ methanol, $3.1 \%$ acetonitrile, $0.1 \mathrm{M} \mathrm{Na}_{2} \mathrm{PO}_{4}, \mathrm{pH} \mathrm{6.8.} \mathrm{Quantitation} \mathrm{of} \mathrm{the}$ various amino acids was performed after electrochemical detection (ESA 5500 coulochem electrode array system detector) of the eluted peaks from the HPLC, and the data normalized to the protein content of the sample.

Neurofilament protein assay. The assay for neurofilament protein content was carried out according to the method of Doherty et al. (1984). Cultures were washed three times in PBS, and fixed in 4\% paraformaldehyde in phosphate buffer for a period of $2 \mathrm{hr}$ at $4^{\circ} \mathrm{C}$. Following three washes in PBS, the cells were permeabilized by incubation with PBS containing $0.1 \%$ Triton $X-100$ for $15 \mathrm{~min}$, and then further incubated for $60 \mathrm{~min}$ in PBS containing 10\% FCS to block nonspecific binding sites. The cultures were then incubated with the anti-neurofilament mouse monoclonal antibody RT-97 for $60 \mathrm{~min}$ at room temperature, in PBS $/ 10 \% \mathrm{FCS}$, washed three times in PBS $/ 10 \% \mathrm{FCS}$, and further incubated with sheep anti-mouse IgG conjugated to HRP (Jackson Labs) for $60 \mathrm{~min}$. The cells were then washed three times with PBS, and twice with distilled $\mathrm{H}_{2} \mathrm{O}$, and subsequently exposed to $0.2 \% o$-phenylenediamine (OPD) and $0.2 \%$ sodium citrate buffer. After $30 \mathrm{~min}$, the conversion of OPD to its oxidized product was stopped by the addition of $4.5 \mathrm{M} \mathrm{H}_{2} \mathrm{SO}_{4}$. Aliquots of the reaction mixture were removed for determination of optical density at $492 \mathrm{~nm}$ using a Flow Titretek multiscan apparatus.

Glutamic acid decarboxylase activity. Measurement of GAD enzymatic activity was carried out according to the method of Kimura and Kuriyama (1975). Cultures were harvested in $50 \mathrm{mM} \mathrm{KH}_{2} \mathrm{PO}_{4}$ containing $0.25 \%$ Triton X-100. Briefly, $5.2 \mu \mathrm{l}$ of the extract was reacted with ${ }^{14} \mathrm{C}$-glutamate and saturating concentrations of cofactors for $2 \mathrm{hr}$ at $37^{\circ} \mathrm{C}$. The reaction was stopped with $\mathrm{H}_{2} \mathrm{SO}_{4}$, and the vessels were further incubated for 60 min to achieve quantitative absorption of ${ }^{14} \mathrm{CO}_{2}$ by hyamine base. The radioactivity was measured by scintillation spectrometry.

Tyrosine hydroxylase activity. Measurement of TII enzymatic activity was carried out according to the method of Acheson et al. (1984). Cells were harvested from $60 \mathrm{~mm}$ culture dishes in $100 \mu \mathrm{l}$ of $20 \mathrm{~mm}$ Tris, $0.1 \%$ Triton $\mathrm{X}-100, \mathrm{pH} 8.6$. Extracts were assayed immediately after a brief sonication to insure complete disruption of cells. The radioactivity was measured by scintillation spectrometry.

Northern blot analysis of trkB and trkC expression. Cultures were prepared as described above, and treated with BDNF $(50 \mathrm{ng} / \mathrm{ml})$ or NT-3 $(20 \mathrm{ng} / \mathrm{ml})$ for various periods of time. Total RNA was prepared following the procedure of Chomczynski and Sacchi (1987). The RNA samples ( $4 \mu \mathrm{g} /$ lane) were fractionated in agarose-formaldehyde gels and 
Table 1. BDNF, NT-3, and NT-4/5 increase TH activity in mesencephalic cultures

\begin{tabular}{lc} 
Treatment & $\begin{array}{l}\text { TH activity } \\
\text { (\% control) }\end{array}$ \\
\hline Control & $100 \pm 3$ \\
BDNF $(50 \mathrm{ng} / \mathrm{ml})$ & $152 \pm 1^{* *}$ \\
NT $-3(1 \mathrm{ng} / \mathrm{ml})$ & $159 \pm 8^{* *}$ \\
NT $-4 / 5(2.5 \mathrm{ng} / \mathrm{ml})$ & $132 \pm 2^{* *}$ \\
NGF $(25 \mathrm{ng} / \mathrm{ml})$ & $93 \pm 5$
\end{tabular}

Cultures prepared from $\mathrm{E} 14$ ventral mesencephalon were maintained for $7 \mathrm{~d}$ in the presence or absence of one of the neurotrophins as indicated. TH activity was determined on day 8 . Results are expressed as a percentage of TH activity in the untreated, control cultures and represent the mean \pm SEM, $n=3$ or 4 . TH activity in control cultures was $0.7 \mathrm{fmol} / 8 \mathrm{~min} / \mu \mathrm{g}$ protein

** $p<0.005$, Student's $t$ test.

transferred to nylon membrane (MSI) as described by Maniatis (1982). Blots were hybridized with a ${ }^{32} \mathrm{P}$-cRNA rat TrkB probe spanning a sequence that includes a portion of the coding region for the intracytoplasmic kinase domain, as well as the remaining C-terminal amino acids and a short (211 base pair) $3^{\prime}$ untranslated sequence (nucleotide bases 2545-3126). The TrkC cDNA probe used for these studies consisted of a 330 base sequence, ${ }^{32} \mathrm{P}$-labeled by random hexamer labeling as previously described (Maisonpierre et al., 1990b), and corresponds to that portion of the extraccllular domain of TrkC cncoded by nucleotides $1-309$.

Localization of trkB and trkC expression in adult brain by in situ hybridization. Adult female Sprague-Dawley rats (200-325 gm) were killed, and the brains removed and frozen in methylbutane at $-20^{\circ} \mathrm{C}$. Coronal sections $(10 \mu \mathrm{m})$ cut on a cryostat were processed for in situ hybridization localization using probes to TrkB kinase domain and TrkC extracellular domain. Riboprobes were transcribed in the presence of ${ }^{35} S$-cytosine triphosphate using $T_{3}$ or $T$, RNA polymerase (Promega) for the generation of "antisense" and "sense" sequences. The antisense RNA sequence used for the TrkB localization studies was a 526-baselong RNA, complementary to a portion of the region encoding the intracytoplasmic tyrosine kinase domain of rat TrkB (nucleotide bases 2300-2823). The RNA sequence used for TrkC localization was a 330basc-long RNA, complementary to a portion of the region encoding the extracellular domain of rat TrkC (nucleotide bases 1-309). The processing of the sections through the prehybridization and hybridization steps was carried out as described by Friedman et al. (1992). Finally, sections were dried through ascending alcohol concentrations and exposed to Amersham Hyperfilm MP for $7 \mathrm{~d}$. Following development, the slides were dipped in Kodak NTB-2 emulsion diluted 1:1 (v/v) with $2 \%$ glycerol. Emulsion autoradiograms were allowed to expose for 5-6 weeks, developed in Kodak D-19, counterstained with cresyl violet, and coverslipped
Purification of neurotrophins. Recombinant human BDNF and NT-3 were prepared and purified as previously described (DiStefano et al., 1992; Spina et al., 1992). Murine NGF was purified as described by Bocchini and Angeletti (1969), and kindly supplied by Dr. R. Alderson (Regeneron, Tarrytown, NY). BDNF and NT-3 were generously provided by Dr. J. Miller (Amgen, Thousand Oaks, CA). Human recombinant NT-4/5 expressed in $E$. coli was generously provided by Drs. J. Fandl and N. Tobkes (Regeneron). Biological activity of each of the neurotrophins was routinely assayed in cultures of chick cmbryo PNS neurons.

\section{Results}

\section{Effect of neurotrophins on dopaminergic neurons}

Confirming earlier reports (Hyman et al., 1991; Knüsel et al., 1991), BDNF promoted the survival and differentiation of dopaminergic neurons in cultures of embryonic rat ventral mesencephalon. As shown in Figure $1 A, 7 \mathrm{~d}$ of treatment with BDNF elicited a dose-dependent elevation of TH-positive neuron number, with a maximal 3 -fold increase at $25 \mathrm{ng} / \mathrm{ml}$. Similar cultures maintained in the presence of NT-3 for $7 \mathrm{~d}$ displayed a maximal increase of 2.3-fold in TH-positive neurons, which was reached at between 2.5 and $5.0 \mathrm{ng} / \mathrm{ml}$ (see Fig. $5 B$ ). This effect of NT-3 was dose dependent but, unlike BDNF, the highest concentration of NT -3 tested $(25 \mathrm{ng} / \mathrm{ml})$ produced a submaximal effect. Addition of NT-4/5 to cultures every other day, as shown in Figure $1 C$, was found to produce the most robust effect of all the neurotrophins tested, elevating the dopaminergic cell number by 6.9 -fold at a concentration of $10 \mathrm{ng} / \mathrm{ml}$. As was the case for NT-3, the highest concentration tested $(25 \mathrm{ng} / \mathrm{ml})$ led to a slight attenuation of the increase in dopaminergic cell number. The effective concentration ranges for NT-3 and NT-4/5 were also similar. As summarized in Table 1, treating cultures for 1 week with BDNF, NT-3, or NT-4/5 increased the levels of TH enzymatic activity, as measured radiometrically.

To compare further the effects of the neurotrophins on dopaminergic neurons we determined high-affinity DA uptake activity in control and treated cultures. Replicate cultures were assayed for both high-affinity DA uptake and the number of TH-positive neurons, such that the DA uptake valucs obtained could be normalized to the number of dopaminergic neurons. Following $3 \mathrm{~d}$ in vitro, DA uptake activity was the same in control and BDNF-treated cultures, $2.14 \pm 0.25$ and $2.25 \pm$ $0.08 \mathrm{cpm} / 15 \mathrm{~min} / \mathrm{TH}$ neuron, respectively. After $6 \mathrm{~d}$ in vitro, there was a large increase in DA uptake capacity relative to the
A

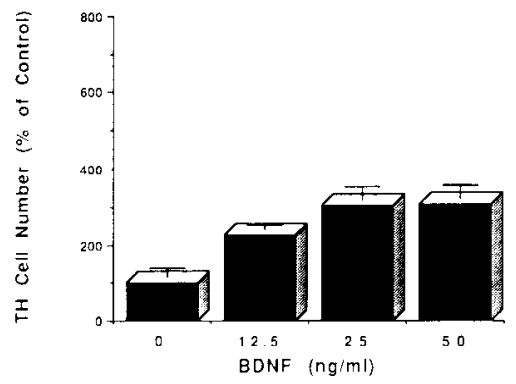

B

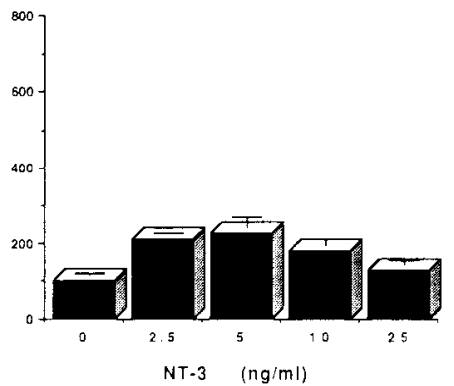

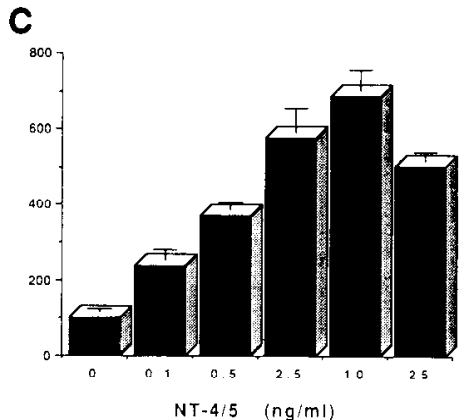

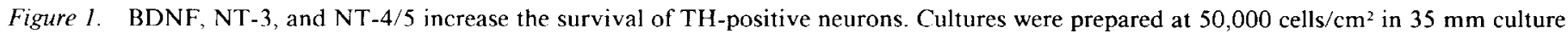
dishes. Upon media change to serum-free conditions, triplicate cultures were exposed to increasing concentrations of either BDNF, NT-3 (given as single additions at the day of plating), or NT-4/5 (given as every other day multiple additions). The cultures were maintained for $7 \mathrm{~d}$ in vitro, and were subsequently processed for $\mathrm{TH}$ immunocytochemical analysis. The number of $\mathrm{TH}$-positive neurons present in each culture was then determined microscopically. Data are expressed as a percentage of the TH-positive neurons counted in control cultures (no neurotrophin addition). Results here and in subsequent figures represent the mean \pm SD where $n=3$ or greater. 


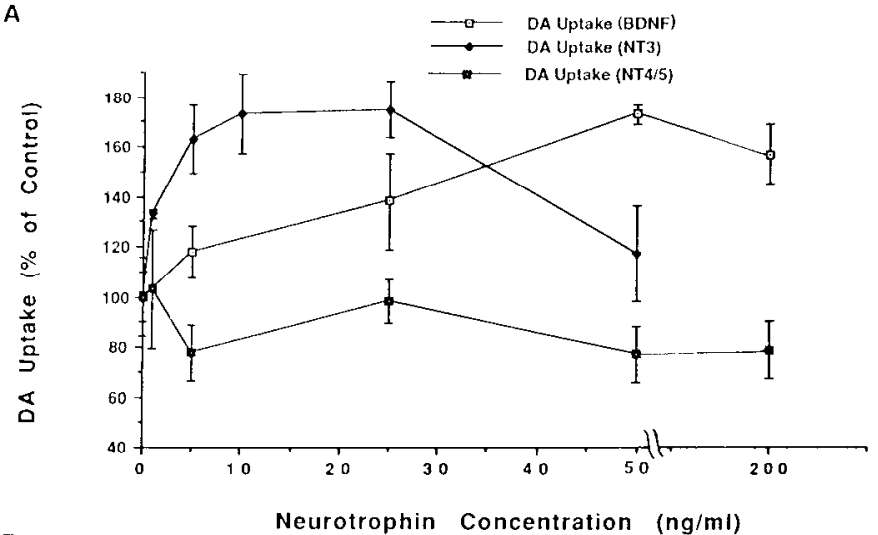

B

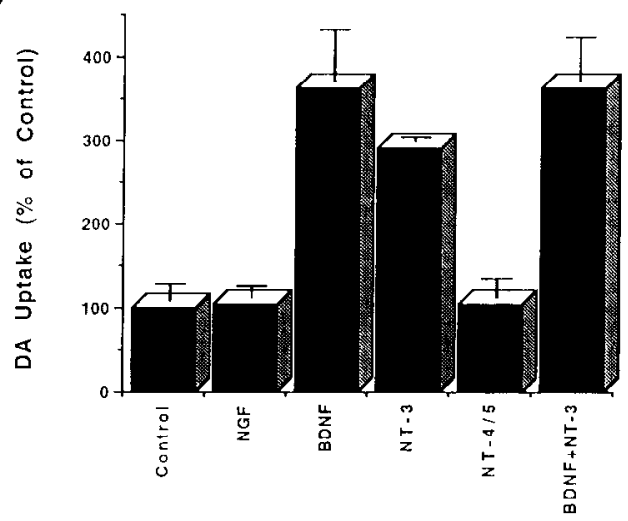

Figure 2. Effects of BDNF, NT-3, and NT-4/5 on high-affinity DA uptake activity. Cells were plated at 50,000 cells $/ \mathrm{cm}^{2}$ or 100,000 cells/ $\mathrm{cm}^{2}$ ( $A$, BDNF dose response) in $35 \mathrm{~mm}$ culture dishes. Upon media change to serum-free conditions, cultures, five to a group, were exposed to increasing concentrations of either BDNF, NT-3, or NT-4/5. $A$. Doseresponse curves for BDNF, NT-3, and NT-4/5. DA uptake activity is expressed as a percentage of the control value measured in untreated cultures. $B$. Results obtained from cultures grown in the absence or presence of NGF $(50 \mathrm{ng} / \mathrm{ml})$, BDNF $(50 \mathrm{ng} / \mathrm{ml}), \mathrm{NT}-3(25 \mathrm{ng} / \mathrm{ml})$, NT$4 / 5(2.5 \mathrm{ng} / \mathrm{ml})$, or a combination of $50 \mathrm{ng} / \mathrm{ml} \mathrm{BDNF}$ and $12.5 \mathrm{ng} / \mathrm{ml}$ NT-3. The cultures were maintained in vitro for a period of $7 \mathrm{~d}$. Results are expressed relative to controls.

three day cultures, in agreement with previously published studies (Tomozawa and Appel, 1986). However, the DA uptake value in control and BDNF-treated cultures was not significantly different $(62.5 \pm 7.8$ vs. $83.3 \pm 12.0 \mathrm{cpm} / 15 \mathrm{~min} / \mathrm{TH}$ neuron, respectively). Thus, on a per neuron basis, BDNF treatment did not lead to increased DA uptake capacity, rather BDNF treatment caused a coordinate increase in both $\mathrm{TH}$-positive neurons and high-affinity DA uptake.

Results of individual and combinatorial actions of the neurotrophins on the high-affinity DA uptake activity of the cultures are shown in Figure 2. Both BDNF and NT-3 produced saturable dose-dependent increases in DA uptake activity (Fig. $2 A$ ). The dose responses for DA uptake were similar to those observed for the elevation of TH-positive neuron number (Fig. 1). In marked contrast, and despite potent effects in elevating the number of TH-immunoreactive neurons, NT-4/5 was without effect on high-affinity DA uptake.

In order to determine whether BDNF and NT-3 have distinct or broadly overlapping effects on dopaminergic neuron phenotype, additivity experiments were carried out in which cultures were exposed to saturating concentrations of BDNF, NT3 , NT-4/5, or combinations of these neurotrophins. High-affinity DA uptake after $7 \mathrm{~d}$ in vitro was used as a measure of possible

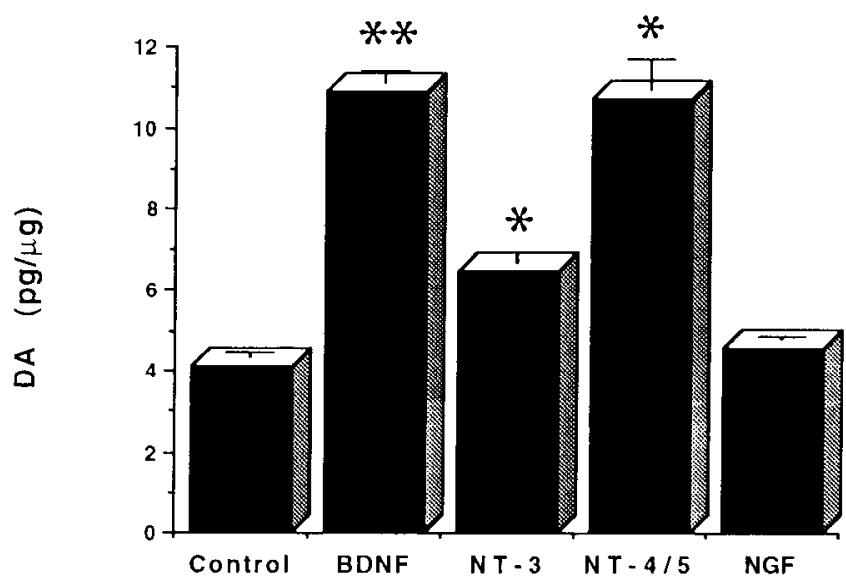

Figure 3. BDNF, NT-3, and NT-4/5 increase DA content of mesencephalic cultures. Cultures plated at 50,000 cells $/ \mathrm{cm}^{2}$ into $60 \mathrm{~mm}$ culture dishes were treated with murine NGF $(50 \mathrm{ng} / \mathrm{ml})$, human recombinant BDNF $(10 \mathrm{ng} / \mathrm{ml}), \mathrm{NT}-3(10 \mathrm{ng} / \mathrm{ml})$, or NT $-4 / 5(2.5 \mathrm{ng} / \mathrm{ml})$. The cultures were maintained in vitro for $8 \mathrm{~d}$, and then processed for DA determination as described. Results are expressed as DA content in $\mathrm{pg} / \mu \mathrm{g}$ protein $(n=6)$. Data are the mean \pm SEM. ${ }^{* *}, p<0.001 ;{ }^{*}, p<0.05 ;$ compared to control, Student's $t$ test.

additive or synergistic effects of combinations of BDNF and NT-3. The results of a representative experiment are shown in Figure $2 B$, where the combination of BDNF and NT-3 had no greater effect than either factor alone. Individually, NGF and NT-4/5 were without effect, and combinations with either of these two factors and BDNF or NT-3 did not alter the extent to which the uptake was elevated (data not shown). The absence of any additivity between BDNF and NT-3 suggests that their actions are exerted either through a common receptor (i.e., TrkB) or through saturation of a common transduction pathway.

Further evidence of effects of the neurotrophins on nigral dopaminergic neurons was obtained by measuring DA levels. As shown in Figure 3, BDNF, NT-3, and NT-4/5 all produced increases in the DA content of cultures grown with these factors for $8 \mathrm{~d}$. Consistent with earlier reports showing a lack of NGF effect on dopaminergic neurons (DalToso et al., 1988; Knüscl et al., 1990), NGF treatment did not change DA content.

\section{Effect of neurotrophins on GABAergic neurons}

To examine possible effects of the neurotrophins on nigral GABAergic neurons, high-affinity GABA uptake, GABA content,

Table 2. Effects of neurotrophin treatment on the number of GADpositive neurons in mesencephalic cultures

GAD-positive neurons

Treatment (cells $/ \mathrm{cm}^{2}$ )

Control

BDNF $(50 \mathrm{ng} / \mathrm{ml})$

$\mathrm{NT}-3(20 \mathrm{ng} / \mathrm{ml})$

$\mathrm{NT}-4 / 5(2.5 \mathrm{ng} / \mathrm{ml})$

NGF $(25 \mathrm{ng} / \mathrm{ml})$

$300 \pm 70$

$362 \pm 16$

$489 \pm 30^{*}$

$414 \pm 54$

$397 \pm 14$

Cultures prepared from El4 ventral mesencephalon were maintained in $35 \mathrm{~mm}$ dishes for $7 \mathrm{~d}$ in the presence or absence of one of the neurotrophins as indicated. Immunocytochemical staining for GAD was carried out as in Materials and Methods. GAD-positive neurons were counted in random fields covering one-third of the dish. Results represent the mean $\pm \operatorname{SEM}(n=4)$.

${ }^{*} p<0.05$, Student's $t$ test. 

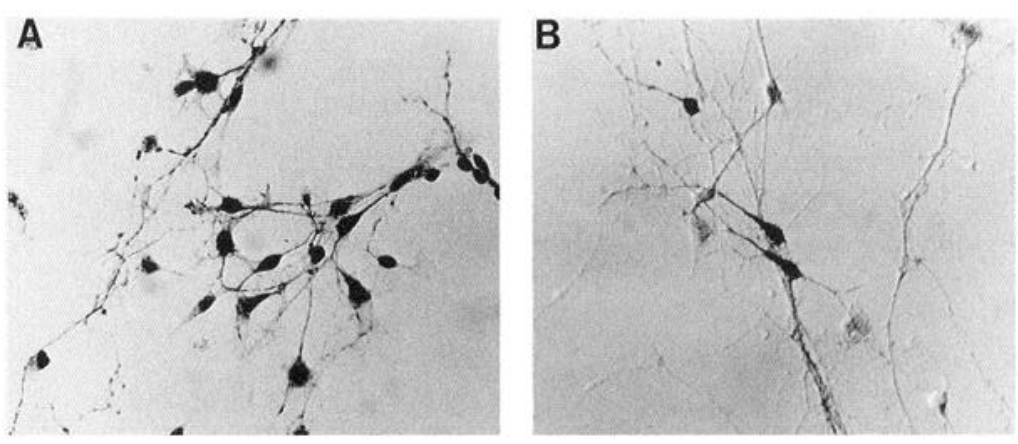

Figure 4. Immunocytochemical staining of GABAergic neurons with anti$\mathrm{GAD}_{67}$ antiserum. Cells were prepared as described and plated at 50,000 cells/ $\mathrm{cm}^{2}$ in $35 \mathrm{~mm}$ culture dishes. After 3, 6 , and $10 \mathrm{~d}$, cultures were processed for immunocytochemical staining using a polyclonal antiserum directed against recombinant feline GAD (courtesy Dr. A. Tobin, UCLA). $A-C$, Photomicrograph of GAD-positive cells in 3,6, and $10 \mathrm{~d}$ cultures, respectively. $D$, Control indicating the lack of staining obtained in the absence the primary antibody using cultures maintained for $7 \mathrm{~d}$ in vitro. Scale bar, $100 \mu \mathrm{m}$.
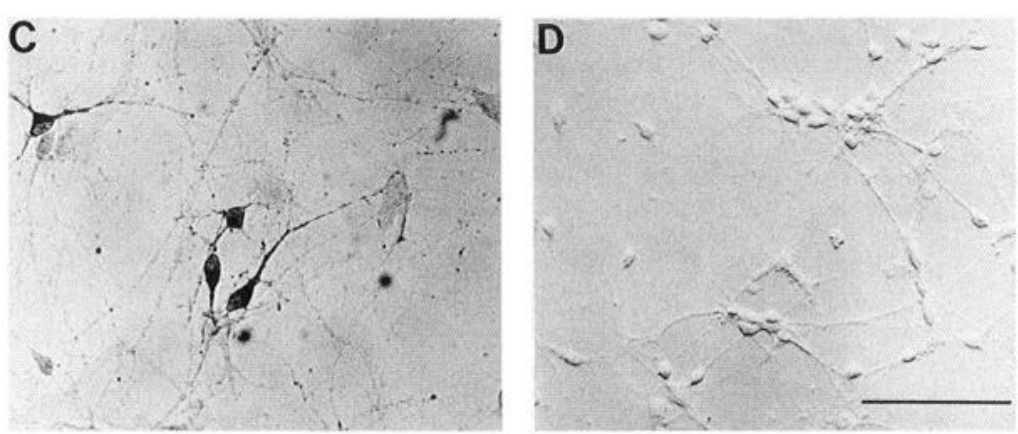

and GAD activity were measured in control and treated cultures. The presence of GABAergic neurons in the cultures was first detected by immunocytochemical staining using an antibody specifically directed against the $67 \mathrm{kDa}$ form of GAD, which is found in terminal processes and neuronal perikarya (Gonzales et al., 1991; Kaufman et al., 1991). Figure 4 shows representative GAD staining patterns obtained in cultures maintained in the absence of any neurotrophic factors for 4,7 , or $11 \mathrm{~d}$ (Fig. $4 A-$ $C$, respectively). No staining was observed in the absence of primary antibody (Fig. $4 D$ ). Cell counts indicated that the number of GAD-positive neurons in cultures maintained for 1 week in vitro in the absence of neurotrophins represented $3.3 \pm 0.7 \%$ of the total cell count at that time. As shown in Table 2, only NT-3 produced a significant increase $(63 \%)$ in the number of GAD-positive neurons after $7 \mathrm{~d}$ in vitro.

Although BDNF did not increase the number of GAD-positive neurons, BDNF as well as NT-3 produced dose-dependent increases in GAD enzymatic activity in cultures maintained for $7 \mathrm{~d}$, as shown in Figure 5, $A$ and $B$, respectively. NT-3 produced a greater increase than BDNF (3-fold vs 1.8-fold), whereas NT$4 / 5$ was without effect at any concentration tested (Fig. $5 C$, and up to $200 \mathrm{ng} / \mathrm{ml}$, data not shown).

As another marker of GABAergic neurons, we explored the effects of each of the neurotrophins on the high-affinity GABA uptake capacity of cells cultured for $7 \mathrm{~d}$. As shown in Figure $6 A$, all three neurotrophins tested (BDNF, NT-3, and NT-4/5) elicited increases of two- to threefold in GABA uptake. The dose responses of BDNF and NT-3 were similar, reaching maxima at approximately $20 \mathrm{ng} / \mathrm{ml}$. NT-4/5 was effective at lower concentrations than BDNF or NT-3, saturating at $10 \mathrm{ng} / \mathrm{ml}$ with decreased effects at higher concentrations. When we assessed possible additive or synergistic effects on GABA uptake, no combinatorial effects of any of the neurotrophins were observed (Fig. 6B). NGF (50 ng/ml) had no effect on GABA uptake activity.

As a further marker of the GABAergic phenotype, we measured GABA content in cultures treated with each of the neurotrophins (Fig. 7). BDNF, NT-3, and NT4/5 all produced mod-
A

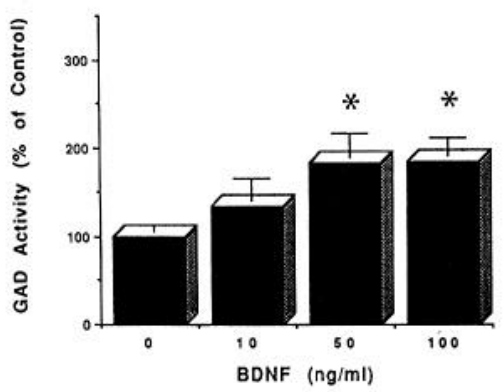

B

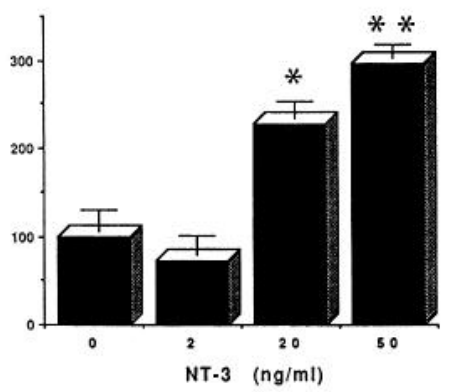

C

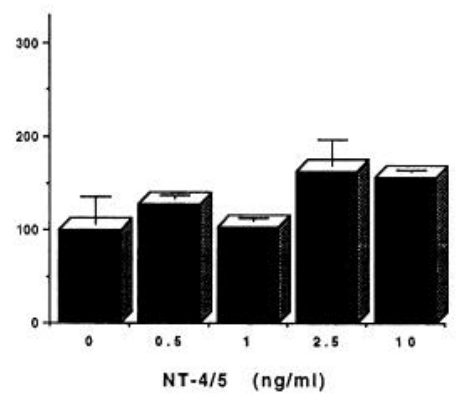

Figure 5. BDNF and NT-3 increase GAD activity in mesencephalic cultures. Cells were prepared as described, and plated at 50,000 cells $/ \mathrm{cm}^{2}$ in $35 \mathrm{~mm}$ dishes. Upon media change after the initial attachment period, cultures were exposed to increasing concentrations of either BDNF, NT-3, or NT-4/5 ( $n=5$ per group). All cultures were maintained for $7 \mathrm{~d}$ in vitro, and were then processed for the measurement of GAD as described. GAD activity is expressed as a percentage of the control value determined in untreated cultures. The baseline GAD activity in untreated control samples was calculated as $6.23 \pm 0.39 \mathrm{pmol} / 120 \mathrm{~min} / \mu \mathrm{g}$ protein. ${ }^{* *}, p<0.01 ;{ }^{*}, p<0.05$; compared to control, Student's $t$ test. 
A
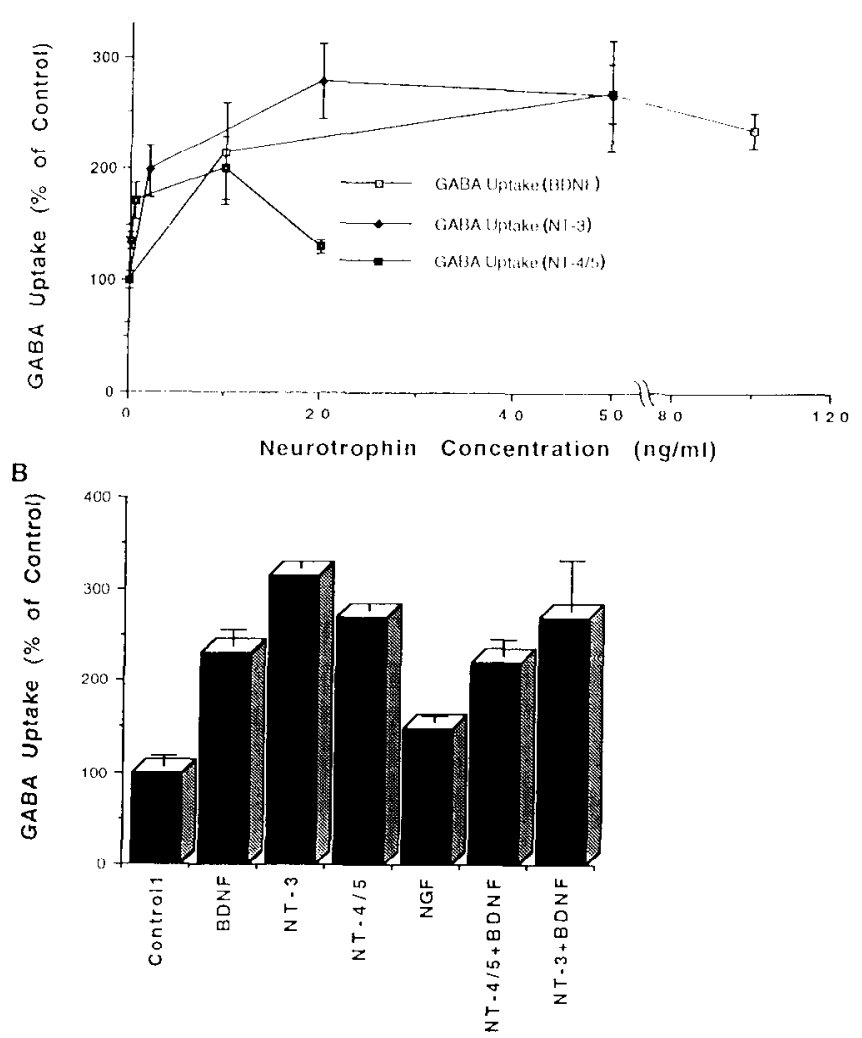

Figure 6. Effects of BDNF, NT-3, and NT-4/5 on high-affinity GABA uptake activity. Cells were plated at 50,000 cells $/ \mathrm{cm}^{2}$ in $35 \mathrm{~mm}$ dishes. After the initial attachment period, the culture medium was changed to a serum-free formulation, and BDNF, NT-3, or NT-4/5 was added in increasing concentrations. After $7 \mathrm{~d}$, cultures were processed for the measurement of high-affinity GABA uptake as described. $A$, Doseresponse curves for BDNF, NT-3, and NT-4/5. The GABA uptake activities are expressed as a percentage of the GABA uptake determined in control cultures. $B$, GABA uptake activity determined in cultures which were maintained in vitro in the presence of either $25 \mathrm{ng} / \mathrm{ml} \mathrm{BDNF}$, $10 \mathrm{ng} / \mathrm{ml} \mathrm{NT}-3,2.5 \mathrm{ng} / \mathrm{ml} \mathrm{NT}-4 / 5,50 \mathrm{ng} / \mathrm{ml} \mathrm{NGF}$, or combinations of BDNF and NT -3 or NT $-4 / 5$ at these same concentrations. The baseline GABA uptake activity in untreated control cultures was calculated as $41,358 \pm 2161 \mathrm{cpm} / 15 \mathrm{~min} / \mathrm{dish}$.

est but significant increases in the GABA content of cultures grown with these factors for $7 \mathrm{~d}$. Again, NGF treatment was without effect. These data are consistent with the increases observed in the high-affinity GABA uptake activity measurements.

\section{Analysis of Trk receptor distribution in substantia nigra}

To address the question of the site of action of the neurotrophins in mediating the above effects on cultured nigral neurons, it was of interest to ascertain the expression pattern of high-affinity BDNF and NT-3 receptors (TrkB and TrkC, respectively) in both embryonic cultures and adult rat brain s. nigra. As shown in Figure 8 , in situ hybridization clearly indicated high levels of TrkB (Fig. $8 B, C$ ) and TrkC (Fig. $8 D-F$ ) mRNA in both the VTA and s. nigra of adult rat brain. The distribution of TrkC is more widespread than TrkB. Examination of the TrkC localization pattern at higher magnification (Fig. $8 E, F$ ) demonstrates that TrkC is expressed in large perikarya, indicative of neurons.

To ascertain if TrkB and TrkC are expressed in embryonic rat ventral mesencephalic tissue, RNA prepared from E14 mesencephalic cultures grown in the presence or absence of BDNF

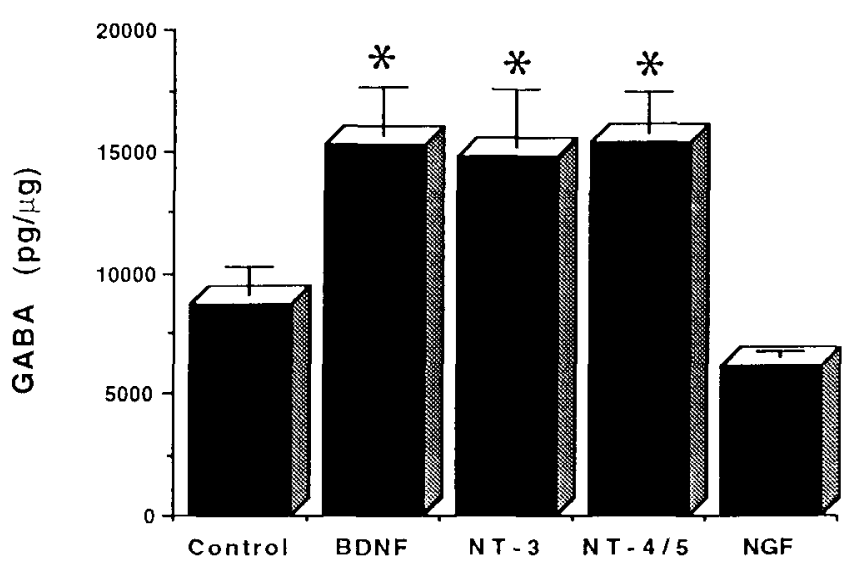

Figure 7. BDNF, NT-3, and NT-4/5 increase the GABA content of mesencephalic cultures. Cultures were prepared as described, and plated at 50,000 cells $/ \mathrm{cm}^{2}$ into $35 \mathrm{~mm}$ dishes. Upon change to serum-free media, BDNF $(50 \mathrm{gm} / \mathrm{ml}), \mathrm{NT}-3(10 \mathrm{ng} / \mathrm{ml}), \mathrm{NT}-4 / 5(2.5 \mathrm{ng} / \mathrm{ml})$, or $\mathrm{NGF}(50 \mathrm{ng} / \mathrm{ml})$ was added ( $n=6$ per group). Cultures were maintained for $7 \mathrm{~d}$ before being processed for GABA determination as described. The GABA content is expressed as $\mathrm{pg} / \mu \mathrm{g}$ protein $(n=6)$. Data are the mean \pm SEM. ${ }^{*}, p<0.05$ compared to control, Student's $t$ test.

or NT-3 for various times was probed by Northern blot analysis. As shown in Figure $9 A$, a probe to the kinase domain of TrkB indicated the presence of a 9 kilobase $(\mathrm{kb})$ transcript under all conditions. Exposure of cultures to BDNF or NT-3 for up to $29 \mathrm{hr}$ did not substantially alter the expression levels of TrkB mRNA. The $9 \mathrm{~kb}$ transcript detected is one of the two brainspecific transcripts described by Klein et al. (1990), and was shown to correspond to the full-length TrkB tyrosine kinase cell surface receptor. In the blot probed for TrkC (Fig. 9C), a $14 \mathrm{~kb}$ transcript was detected both in adult brain and E14 ventral mesencephalon culture RNA. This species has been identified as the major transcript encoding full-length TrkC (Valenzuela et al., 1993). The expression level of this transcript was not strikingly altered in NT-3-treated cultures. An additional $5 \mathrm{~kb}$ TrkC transcript was detected. Migrating just above the $28 \mathrm{~S}$ ribosomal RNA band, this is one of two known transcripts that encode truncated forms of TrkC (Valenzuela et al., 1993).

\section{Discussion}

Numerous studies have demonstrated that the survival and/or differentiation of cultured dopaminergic neurons is enhanced by exogenously added factors, widely ranging in their degree of purity and characterization. Several reports have described trophic activities for nigral dopaminergic neurons in the major target field of these cells, the striatum (Tomozawa and Appel, 1986; DalToso et al., 1988; Carvey et al., 1989, 1991; Nijima et al., 1990). However, the nature of the trophic agent(s) described in these studies remains poorly understood. In addition, it is open to question whether or not the striatum is likely to be the sole source of trophic support for neurons of nigrostriatal pathways. It is possible that locally acting growth factors produced in the s. nigra could, through paracrine or autocrine action, provide trophic support for nigrostriatal neurons. In support of this, BDNF and NT-3 mRNA have been localized to the s. nigra in both adult and developing rat (Friedman et al., 1991; Gall et al., 1992). BDNF has been shown to be trophic for embryonic rat nigral dopaminergic neurons (Hyman et al., 1991; Knüsel et al., 1991). In this report, we extend these findings, demonstrating that BDNF, NT-3, and NT4/5, but not 
Figure 8. Localization TrkB and TrkC mRNA in adult rat $\mathrm{s}$. nigra: dark-field photomicrographs of coronal sections of adult rat brain showing the autoradiographic localization of hybridization signal to mRNA encoding $\operatorname{TrkB}(B$, $C)$ and $\operatorname{TrkC}(D, F) . A$, Schematic illustration of a cross section of the area of midbrain that is representative of the brain sections in $B-F . A q$, aqueduct; $S N$, s. nigra. At low magnification $(B)$, TrkB mRNA is detected in the VTA and medial s. nigra. $C$, Higher magnification of the left hemisphere, ventral aspect of the tissue section shown in $B . D$, A tissue section corresponding to that in $C$, hybridized to TrkC cRNA. $E$ and $F$, High-magnification pair of matching bright-field/dark-field photomicrographs of the tissue section in $D$, showing the autoradiographic localization of TrkC hybridization to large perikarya, presumed to be neurons. Scale bar: 3125 $\mu \mathrm{m}$ for $B ; 2185 \mu \mathrm{m}$ for $C$ and $D ; 546$ $\mu \mathrm{m}$ for $E$ and $F$.

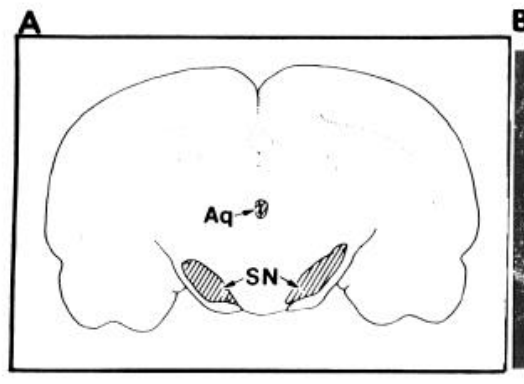

C

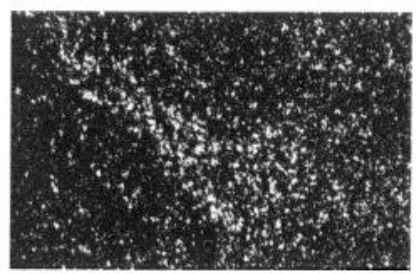

$\mathbf{E}$

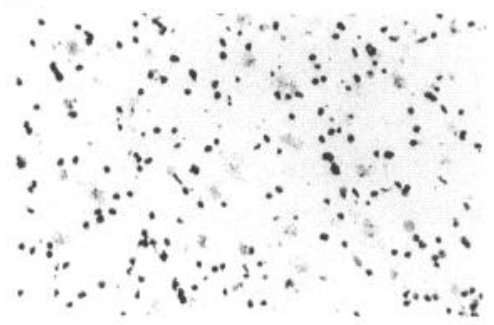

B

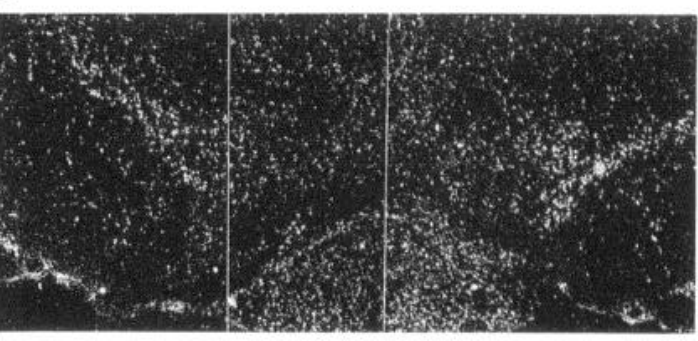

D

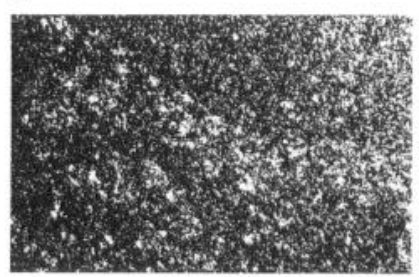

$\mathbf{F}$

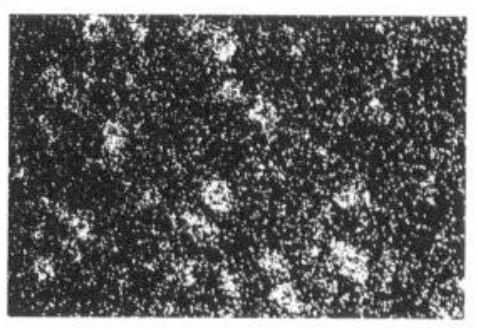

NGF, have overlapping yet distinct effects on embryonic nigral dopaminergic and GABAergic neurons. In agreement with a recent report (Merlio et al., 1992) and consistent with a continuing role of the neurotrophins in the maintenance of mature nigral neurons, high-affinity receptors for BDNF and NT-4/5, and NT-3 (TrkB and TrkC, respectively) have been localized to the s. nigra in adult rat brain. In addition, TrkB and TrkC mRNA was detected in cultures derived from E14 ventral mesencephalon. These findings suggest a direct action of BDNF and NT-4/5, and NT-3 in supporting the survival and/or differentiation of nigral dopaminergic and GABAergic neurons.

As previously described (Hyman et al., 1991; Spina et al., 1992), in the defined medium, serum-free culture conditions used in this study the vast majority of cells have a neuronal morphology. Virtually no astrocytes are detected using antibodies to glial fibrillary acidic protein and few flat fibroblastic cells are evident.

The dose-response data shown in Figure 1 demonstrate that BDNF, NT-3, and NT-4/5 exert their effects on dopaminergic neurons in a dose-dependent, saturable manner. The relative magnitude of the increase in dopaminergic cell number elicited by BDNF and NT-3 was approximately the same, yet saturation was reached for NT-3 at a concentration fivefold less than that required for BDNF. This difference in the relative potency of BDNF and NT-3 appears to be specific for mesencephalic neurons, as the specific activities for BDNF and NT-3 in the standard chick embryo dorsal root ganglion bioassay system are essentially identical (Hory-Lee et al., 1993). Unlike BDNF, NT-3 at higher doses produced a submaximal effect. Of all the neurotrophins, NT-4/5 had the most dramatic effect on dopami- nergic neuronal survival, producing an almost sevenfold increase in $\mathrm{TH}$-positive neurons after 1 week in vitro. In the experiment shown in Figure 1, NT-4/5 was replenished as multiple, every other day additions; similar treatment with BDNF over $8 \mathrm{~d}$ in vitro produced a maximal fivefold increase in $\mathrm{TH}$ positive neurons (Hyman et al., 1991). Interestingly, the effect of NT-3 was essentially the same whether added as a single dose at the beginning of the experiment or when freshly added every other day.

Treatment of cultures with BDNF led to a parallel increase in high-affinity DA uptake activity and the number of THpositive neurons, suggesting that while BDNF promotes dopaminergic neuron survival, it does not induce nerve terminal sprouting in vitro. Assuming relatively uniform distribution of DA uptake sites, one would expect that increased neuritic growth would have led to a proportionally greater increase in DA uptake. Although a systematic morphometric analysis has not yet been carried out, we did not observe any dramatic effects of the neurotrophins on neurite outgrowth from TH-positive neurons, a finding consistent with the recent morphometric data reported by Beck et al. (1993). This is in marked contrast to very striking effects of BDNF and NT-3 on the morphology of striatal GABAergic neurons (Ventimiglia et al., 1993).

Increased DA uptake activity produced by BDNF or NT-3 treatment was shown to be dose dependent and saturable (Fig. 2 ). The effect of BDNF was in agreement with previous findings of Knüsel et al. (1991), but unlike the present data, the same authors found no effect of NT-3 on nigral dopaminergic neurons. Our contrasting findings indicating that NT-3 treatment does increase the survival of nigral dopaminergic neurons may be 
A.
C $\quad$ C
$\begin{array}{llllllll}5 & 16 & 24 & 29 & 5 & 16 & 24 & 29\end{array}$

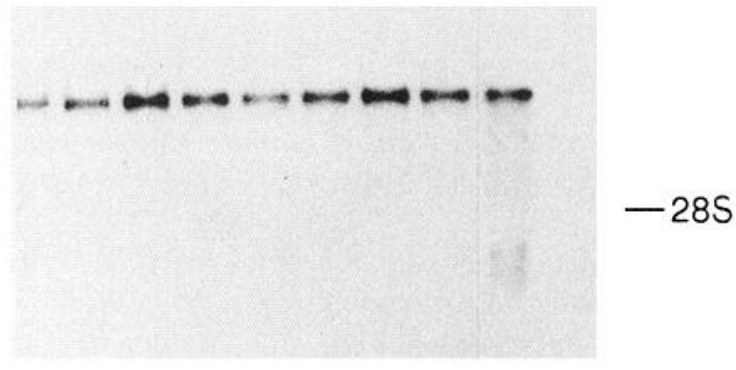

B.

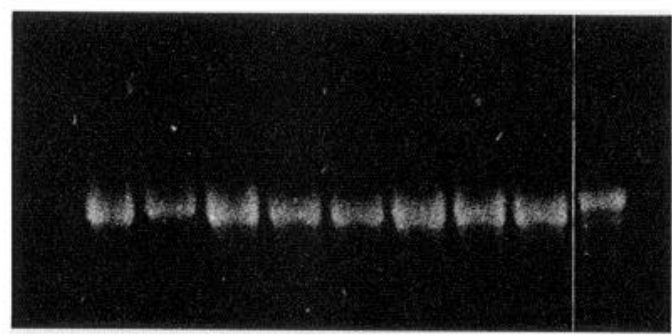

C.

$$
\begin{array}{ccccccc}
\text { TB } & C & N & C & N & C & N \\
& 5 & 5 & 16 & 16 & 24 & 24
\end{array}
$$

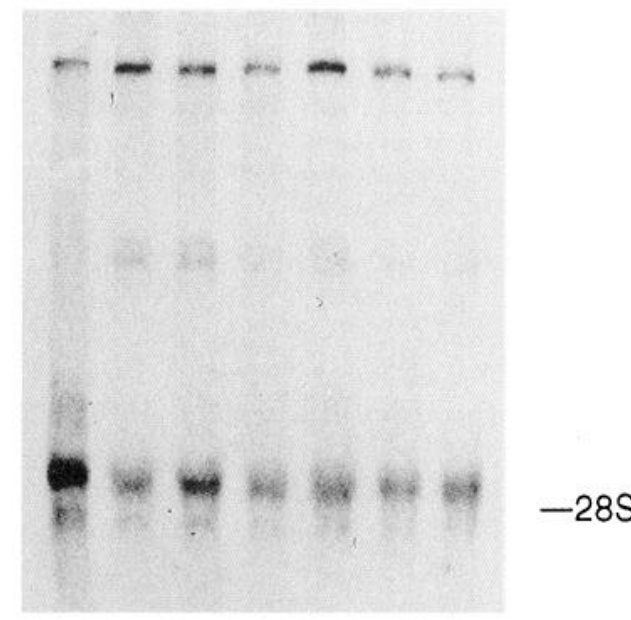

D.

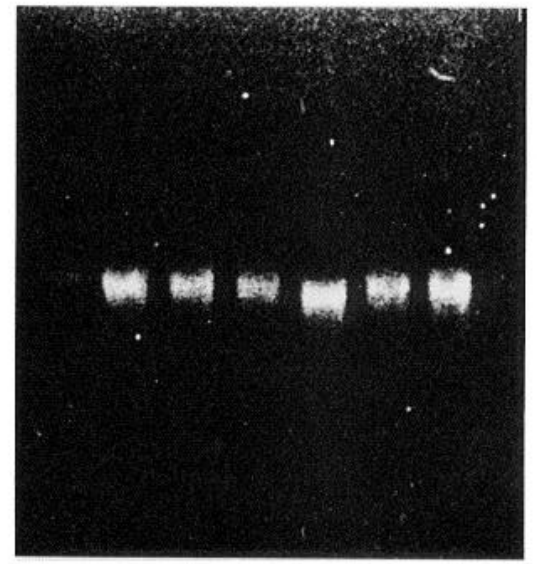

Figure 9. Northern blot analysis of TrkB and TrkC mRNA in cultures derived from E14 ventral mesencephalon. Cells were plated at 50,000 cells $/ \mathrm{cm}^{2}$ into $60 \mathrm{~mm}$ dishes. After maintenance in serum-free conditions for $72 \mathrm{hr}$, BDNF (50 ng/ml) or NT-3 (25 ng/ml) was added and cultures were maintained for $5,16,24$, or $29 \mathrm{hr}$. Northern blots prepared from the cultures were probed for TrkB or TrkC mRNA. A, Autoradiogram of a blot following hybridization with the TrkB probe. $C$, control; $B, \mathrm{BDNF}$; $B$, total adult rat brain RNA. $B$, The corresponding ethidium bromide stained gel. $C$, Autoradiogram of a blot following hybridization with the TrkC probe. $C$, control; $N$, NT - 3 ; $T B$, total brain RNA. $D$, Corresponding ethidium bromide stained gel.

reflective of differences in culture conditions, non-neuronal cell content of the cultures, or the embryonic stage of the tissue that was used to generate the cultures. Curiously, NT-4/5, which had the greatest effect of all the neurotrophins in elevating the number of TH-positive neurons, had no effect on high-affinity DA uptake activity. Thus, the effects of NT-4/5 on the dopaminergic neuron population are apparently distinct as well as overlapping with that observed for BDNF. This suggests that although BDNF and NT-4/5 show equivalence as TrkB ligands when this receptor is expressed in the artificial setting of a fibroblast (Glass et al., 1991; Ip et al., 1992, 1993), in the context of TrkBexpressing neurons, the signal transduction pathways of BDNF and NT-4/5 may not be identical.

BDNF, NT-3, and NT- $4 / 5$ all increased DA content of ventral mesencephalic cultures after $7 \mathrm{~d}$ in vitro. The increased DA content was to be expected, since the number of TH-positive neurons was increased by all these factors. The specificity of this effect was further demonstrated by the lack of any increase in DA content in NGF-treated cultures, entirely consistent with previous studies where NGF has been shown to have no effect on dopaminergic neurons in vitro (DalToso et al., 1988; Knüsel et al., 1990, 1991).

The observation that combinations of BDNF and NT-3 did not produce any greater increase in high-affinity DA uptake over that obtained with either factor alone suggests that TrkB and TrkC are coexpressed on the majority of nigral dopaminergic neurons. Furthermore, it suggests that postreceptor signal transduction elicited by these two neurotrophins may be through a common transduction pathway. It has been documented that NT-3 can bind to the high-affinity receptor for BDNF, TrkB, and elicit a functional response, albeit at higher concentrations than BDNF (Klein et al., 1991b; Squinto et al., 1991). However, in primary neuronal cultures, the concentrations of NT-3 required to elicit effects through TrkB are much higher than those 
required to activate its cognate receptor, TrkC (Ip et al., 1993). Given that the $\mathrm{EC}_{50}$ of the NT-3 response in the uptake assay was less than $2.5 \mathrm{ng} / \mathrm{ml}$ ( $\Gamma$ ig. $2 A$ ), it is unlikely that any of the NT-3 effects were mediated through TrkB.

In this study we have shown that TrkB and TrkC mRNA are expressed in adult rat $\mathrm{s}$. nigra with an expression pattern consistent with dopaminergic neurons. The pattern of in situ hybridization is reminiscent of that observed in retrograde transport studies where iodinated BDNF or NT-3 were injected into striatum of adult rats (Wiegand et al., 1992). Consistent with the observed responses to BDNF and NT-4/5, and NT-3 we have shown that RNA prepared from cultures derived from E14 ventral mesencephalon contains TrkB and TrkC mRNA, as detected by Northern blot analysis, using probes that hybridize to transcripts encoding full-length Trk receptors. Although initial reports of BDNF distribution in adult rat brain indicated low levels of expression in striatum, more recent studies demonstrate a wave of expression of this neurotrophin in early postnatal striatum, consistent with target-derived support of dopaminergic neuron survival (Ventimiglia, personal communication). Moreover, recent in situ hybridization studies have shown expression of BDNF and NT-3 mRNA in both developing and adult rat s. nigra (Friedman et al., 1991; Gall et al., 1992). It is possible that BDNF or NT-3 produced in this area acts on nigral afferents in a target-derived manner, or acts locally in a paracrine or autocrine fashion within the s. nigra itself.

The s. nigra zona reticulata contains GABAergic neurons that are detectable by immunocytochemical staining with anti-GAD antibodies (Oertel et al., 1982; Mugnaini and Oertel, 1985). It is known that this enzyme exists in mammalian brain in two forms $(M$, values 65,000 and 67,000), which are encoded by two different genes (Erlander and Tobin, 1991; Erlander et al., 1991). The two forms differ in their intraneuronal distribution; the $65 \mathrm{kDa}$ form is present primarily in axon terminals whereas the $67 \mathrm{kDa}$ form is present in both terminals and cell bodies (Gonzales et al., 1991; Kaufman et al., 1991). Furthermore, the two forms of this enzyme differ in their relative affinities for the cofactor pyridoxal phosphate (Kaufman et al., 1991). Because of the close topographical relationship between dopaminergic and GABAergic neurons in the s. nigra (Oertel et al., 1982), we assessed the presence and the potential effects of neurotrophins on the latter population of cells in our cultures. In the first instance, immunocytochemical staining was carried out with an antibody directed against the $67 \mathrm{kDa}$ GAD, as in situ hybridization has shown this to be the predominant form of GAD in the s. nigra (Mercugliano et al., 1992). GAD-positive neurons comprised about $3.3 \%$ of the total cell number (as calculated from the total cell count) after $7 \mathrm{~d}$ in vitro. This was approximately sixfold higher than the number of dopaminergic neurons in similar control cultures (Hyman et al., 1991).

Responses of the $\mathrm{G} \wedge \mathrm{B} \wedge$ ergic neurons to neurotrophin treatment were studied by examination of several independent phenotypic markers, including GAD activity, GAD-immunopositive neurons, high-affinity GABA uptake, and measurement of the GABA content of the cultures. The results of experiments with NT-3 treatment suggest that this neurotrophin supports the survival of nigral GABAergic neurons in a manner similar to its effect on nigral dopaminergic neurons. BDNF treatment, while elevating GAD activity, endogenous GABA content, and high-affinity GABA uptake, did not increase the number of GAD-positive neurons. Thus, the primary action of BDNF on nigral GABAergic neurons seems to be toward their phenotypic expression rather than survival. Cotreatment of cultures with BDNF and NT-3 did not lead to an additive effect on the GABAergic neurons as determined by GABA uptake activity. This again suggests coexpression of both TrkB and TrkC on most nigral GABAergic neurons, and a convergence of signal transduction pathways activated by either of these receptors. Similar to the effect observed after BDNF or NT-3 treatment, NT-4/5 led to increases in the GABA content as well as high-affinity GABA uptake activity. However, unlike BDNF and NT-3, NT4/5-treated cultures did not exhibit increased GAD activity. In the case of NT-4/5, the paradoxical finding of increased GABA content in the absence of any effect on GAD activity may be an indication of an inhibition in either GABA metabolism (via transamination and entry in the Kreb's cycle) or release.

Previous reports have shown that nigral dopaminergic and GABAergic neurons are responsive to exogenously added trophic activities present both in crude extracts (Tomozawa and Appel, 1986) as well as partially purified preparations (DalToso ct al., 1988) of striatal tissuc. It is possible that these observations reflect the presence of either BDNF or NT-3 in striatal tissue. Treatment of mesencephalic cultures with bFGF has been reported to lead to increased DA and GABA uptake activities with time in culture (Ferrari et al., 1989). A growing body of evidence suggests that this is most likely to be an indirect effect, mediated through actions of bFGF on astroglial cells (Knüsel et al., 1990; Engele and Bohn, 1991). At the low cell density used in our studies there are very few astrocytes in the cultures even after $8 \mathrm{~d}$ in vitro (Hyman et al., 1991), arguing against such an indirect effect with the neurotrophins. The general pattern of expression of TrkB and TrkC in the adult rat s. nigra is consistent with the neurotrophins BDNF, NT-3, and NT-4/5 having a direct effect on the dopaminergic and GABAergic neurons. More definitive demonstration of this, however, will require colocalization of $\mathrm{TH}$ and $\mathrm{TrkB} / \mathrm{TrkC}$, as well as colocalization of GAD and TrkB/TrkC in this region of brain. The detection in our cultures of trk B and $t r k \mathrm{C}$ transcripts that encode full-length TrkB (Klein et al., 1990) and TrkC (Valenzuela et al., 1993) is again compatible with the observed effects of BDNF and NT-4/5, and NT-3. However, the Northern data alone do not distinguish between an indirect or direct mode of action of neurotrophins toward dopaminergic and GABAergic neurons.

In contrast to the pronounced effects of BDNF, NT-3, and NT-4/5 on dopaminergic and GABAergic neurons, we found no broad effect of the neurotrophins on the great majority of the neurons in the cultures. As determined by immunoassay, the neurofilament protein content of cultures maintained for 7 $\mathrm{d}$ with BDNF $(50 \mathrm{ng} / \mathrm{ml})$ or NT $-3(25 \mathrm{ng} / \mathrm{ml})$ was not found to be significantly different from control cultures (123 $\pm 21 \%$ and $119 \pm 7 \%$, respectively). This suggests that these factors do not exert their effects via a nonspecific or general effect on all neuronal cells in this culture system, and is consistent with a previous report that indicated no change in the overall cell number following BDNF treatment (Hyman et al., 1991).

The neurotrophic effects of BDNF, NT-3, and NT-4/5 reported in this study are clearly distinct from those recently described for glial cell line-derived neurotrophic factor (GDNF) (Lin et al., 1993). While BDNF, NT-3, and NT-4/5 were shown to exert their effects on both dopaminergic and GABAergic neurons, GDNF was found to affect dopaminergic neurons only. In further contrast to the action of BDNF, GDNF was reported to elevate DA uptake activity on a per TH-positive neuron basis. A more detailed description of GDNF effects will be required 
to evaluate it adequately as a specific neurotrophic factor for $\mathrm{s}$. nigra dopaminergic neurons.

The results of the present study extend the rationale for examining the effects of BDNF, NT-3, and NT-4/5 on nigral function in vivo. BDNF, when chronically infused into adult rat brain just above the s. nigra, has recently been shown to elicit an effect on nigral DA neurons that is consistent with augmented DA release (Altar et al., 1992). It may therefore be predicted that BDNF infusion to the s. nigra prior to nigrostriatal lesion could potentiate the function of surviving DA neurons, or protect these neurons from lesion-induced damage. However, the finding that BDNF as well as NT-4/5 and NT-3 have potent actions on cultured GABAergic neurons as well as dopaminergic neurons indicates that interpretation of in vivo studies will also require careful analysis of potential effects of these neurotrophins on nondopaminergic neurons.

\section{References}

Acheson AL, Naujoks K, Thoenen H (1984) Nerve growth factor mediated enzyme induction in primary cultures of bovine adrenal chromaffin cells: specificity and level of regulation. J Neurosci 7:17711780 .

Alderson RF, Alterman AL, Barde YA, Lindsay RM (1990) Brainderived neurotrophic factor increases survival and differentiated functions of rat septal cholinergic neurons in culture. Neuron 5:297-306.

Alexi T, Hefti $F$ (1993) Trophic actions of transforming growth factor $\alpha$ on mesencephalic dopaminergic neurons developing in culture. Neuroscience 55:903-918.

Altar CA, Boylan CB, Jackson C, Hershenson S, Miller J, Wiegand SJ, Lindsay RM, Hyman C (1992) Brain-derived neurotrophic factor augments rotational behavior and nigrostriatal dopamine turnover in vivo. Proc Natl Acad Sci USA 89:11347-11351.

Altar CA, Criden MR, Lindsay RM, DiStefano PS (1993) Characterization and topography of high-affinity ${ }^{125}$ I-neurotrophin-3 binding to mammalian brain. J Neurosci 13:733-743.

Barde Y-A, Edgar D, Thoenen H (1982) Purification of a new neurotrophic factor from mammalian brain. EMBO J 1:549-553.

Beck K, Knüsel B, Hefti $F$ (1993) The naturc of the trophic action of brain-derived neurotrophic factor, des(1-3)-insulin-like growth factor-1, and basic fibroblast growth factor on mesencephalic dopaminergic neurons developing in culture. Neuroscience 52:855-866.

Berkemeier LR, Winslow JW, Kaplan DR, Nikolics K, Goeddel DV, Rosenthal A (1991) Neurotrophin-5: a novel neurotrophic factor that activates trk and trk B. Neuron 7:857-866.

Bocchini V, Angeletti PU (1969) Nerve growth factor: purification as a 30,000 molecular weight protein. Proc Natl Acad Sci USA 64:787794.

Bottenstein JE, Sato GH (1979) Growth of a rat neuroblastoma cell line in serum-free supplemented medium. Proc Natl Acad Sci USA 76:514-517.

Bradshaw RA (1978) Nerve growth factor. Annu Rev Biochem 47: 191-216.

Carvey PM, Ptak LR, Kao L, Klawans H L (1989) Striatal homogenates from animals chronically treated with haloperidol stimulate dopamine and GABA uptake in cultures of rostral mesencephalic tegmentum. Clin Neuropharmacol 12:425-434.

Carvey PM, Ptak LR, Lo ES, Lin DH, Buhrfiend CM, Goetz CG, Klawans HL (1991) Levodopa reduces the growth promoting effects of striatal extracts on rostral mesencephalic tegmentum cultures. Exp Neurol 114:28-34.

Casper D, Mytilineou C, Blum M (1991) EGF enhances the survival of dopamine neurons in rat embryonic mesencephalon primary cell culture. J Neurosci Res 30:372-381.

Chomczynski P, Sacchi N (1987) Single-step RNA isolation by acid guanidium thiocyanate-phenol-chloroform extraction. Anal Biochem 162:156-159.

Cintra A, Cao YH, Oellig C, Tinner B, Bortolotti F (1991) Basic FGF is present in dopaminergic neurons of the ventral midbrain of the rat. Neuroreport 2:597-600.

DalToso R, Giorgi O, Soranzo C, Kirschner G, Ferrari G, Favaron M, Benvegnu D, Presti D, Vicini S, Toffano G, Azzone GF, Leon A
(1988) Development and survival of neurons in dissociated fetal mesencephalic serum-free cell cultures: I. Effects of cell density and of an adult mammalian striatal-derived neuronotrophic factor (SDNF). J Neurosci 8:733-745.

Davies AM, Thoenen H, Barde Y-A (1986) The response of chick sensory neurons to brain-derived neurotrophic factor. J Neurosci 6:1897-1904.

DiPaulo T, Daigle M, Dupont A (1982) Distribution of dopamine in 35 subregions of the rat caudate-putamen: a high performance liquid chromatography with electrochemical detection analysis. J Can Sci Neurol 9:421-427.

DiStefano PS, Fricdman B, Radzicjewski C, Alexander C, Boland P, Schick CM, Lindsay RM, Wiegand SJ (1992) The neurotrophins BDNF, NT-3, and NGF display distinct patterns of retrograde axonal transport in peripheral and central neurons. Neuron 8:983-993.

Doherty P, Dickson JG, Flanigan TP, Walsh TS (1984) Quantitative evaluation of neurite outgrowth on cultures of human foetal brain and dorsal root ganglion cells using an enzyme linked immunoabsorbent assay for human neurofilament protein. J Neurochem 42 : $1116-1122$.

Engele J, Bohn M C (1991) The neurotrophic effects of fibroblast growth factors on dopaminergic neurons in vitro are mediated by mesencephalic glia. J Neurosci 11:3070-3078.

Engele J, Schubert D, Bohn MC (1991) Conditioned media derived from glial cell lines promote survival and differentiation of dopamincrgic ncurons in vitro-role of mesencephalic glia. J Neurosci Res 30:359-371.

Erlander MG, Tobin AJ (1991) The structural and functional heterogeneity of glutamic acid decarboxylase: a review. J Neurochem Res $16: 215-226$.

Erlander MG, Tillakaratne NJK, Feldblum S, Patel N, Tobin AJ (1991) Two genes encode distinct glutamate decarboxylases. Neuron 7:91100.

Ernfors P, Ibáñez CF, Ebendal T, Olson L, Perssön H (1990a) Molecular cloning and neurotrophic activities of a protein with structural similarities to $\beta$-NGF: developmental and topographical expression in the brain. Proc Natl Acad Sci USA 87:5454-5458.

Ernfors P, Wetmore C, Olson L, Perssön H (1990b) Identification of cells in rat brain and peripheral tissues expressing mRNA for members of the nerve growth factor family. Neuron 5:511-526.

Ferrari G, Minozzi MC, Toffano G, Leon A, Skaper SD (1989) Basic fibroblast growth factor promotes the survival and development of mesencephalic neurons in culture. Dev Biol 133:140-147.

Ferrari G, Minozzi M, Toffano G, Leon A, Skaper SD (1990) Basic fibroblast growth factor affects the survival and development of mesencephalic neurons in culture. Adv Exp Med Biol 265:93-100.

Friedman B, Scherer SS, Rudge JS, Helgren M, Morrisey D, McClain J, Wang D-Y, Weigand SJ, Furth ME, Lindsay RM, Ip NY (1992) Regulation of ciliary neurotrophic factor expression in myelin-related schwann cells in vivo. Neuron 9:295-305.

Friedman WJ, Olson L, Perssön H (1991) Cells that express brainderived neurotrophic factor $\mathrm{mRNA}$ in the developing postnatal rat brain. Eur J Neurosci 3:688-697.

Gall CM, Gold SJ, Isackson PJ, Seroogy KB (1992) Brain-derived neurotrophic factor and neurotrophin-3 mRNAs are expressed in ventral midbrain regions containing dopaminergic neurons. Mol Cell Neurosci 3:56-63.

Glass DJ, Nye SH, Hantzopoulos P, Macchi MJ, Squinto SP, Goldfarb M, Yancopoulos GD (1991) trkB mediates BDNF/NT-3-dependent survival and proliferation in fibroblasts lacking the low affinity NGF receptor. Cell 66:405-413.

Gonzales C, Kaufman DL, Tobin AJ, Chesselet MF (1991) Distribution of glutamic acid decarboxylase $(M, 67,000)$ in the basal ganglia of the rat: an immunohistochemical study with a selective cDNAgenerated polyclonal antibody. J Ncurocytol 20:953-961.

Hallböök F, Ibanez CF, Perssön H (1991) Evolutionary studies of the nerve growth factor family reveal a novel member abundantly expressed in Xenopus ovary. Neuron 6:845-858.

Hancock MB (1982) Immunoreactive fiber system in the dorsal columns of the spinal chord. Neurosci Lett 31:247-252.

Hartikka J, Hefti F (1988) Development of septal cholinergic neurons in culture: plating density and glial cells modulate effects of NGF on survival and expression of transmitter-specific cnzymcs. J Neurosci $8: 2967-2985$.

Hatanaka H, Tsukui H, Nihonmatsu I (1988) Developmental change 
in the nerve growth factor action from induction of choline acetyltransferase to promotion of cell survival in cultured basal forebrain neurons from postnatal rat. Dev Brain Res 39:88-95.

Hempstead BL, Martin DZ, Kaplan DR, Parada LF, Chao MV (1991) High-affinity NGF binding requires coexpression of the trk protooncogene and the low-affinity NGF receptor. Nature 350:678-683.

Hendry IA, Stockel K, Thoenen H, Iversen LL (1974) The retrograde axonal transport of nerve growth factor. Brain Res 68:103-121.

Hofer MM, Barde Y-A (1988) Brain-derived neurotrophic factor prevents neuronal death in vivo. Nature 331:261-262.

Hofer M, Pagliusi SR, Hohn A, Leibrock J, Barde Y-A (1990) Regional distribution of brain-derived neurotrophic factor $m$ RNA in the adult mouse brain. EMBO J 9:2459-2464.

Hohn A, Leibröck J, Bailey K, Barde Y-A (1990) Identification and characterization of a novel member of the nerve growth factor/brainderived neurotrophic factor family. Nature 344:339-341.

Hory-Lee F, Russell M, Lindsay RM, Franke E (1993) Neurotrophin-3 supports the survival of developing muscle sensory neurons in culture Proc Natl Acad Sci USA 93:2613-2617.

Hyman C, Hoffer M, Barde Y-A, Juhasz M, Yancopoulos GD, Squinto SP, Lindsay R M (1991) BDNF is a neurotrophic factor for dopaminergic neurons of the substantia nigra. Nature 350:230-232.

Ibáñez CF, Ebendal T, Barbany G, Murray-Rust J, Blundell TL, Perrsön $\mathrm{H}$ (1992) Disruption of the low affinity receptor-binding site in NGF allows neuronal survival and differentiation by binding to the trk gene product. Cell 69:329-341.

Ip NY, Ibáñez CF, Nye SH, McClain J, Jones PF, Gies DR, Belluscio L, Beau MM, Espinoza R III, Squinto SP, Perssön H, Yancopoulos $G$ (1992) Mammalian neurotrophin-4: structure, chromosomal localization, tissue distribution and receptor specificity. Proc Natl Acad Sci USA 89:3060-3064

Ip N, Stitt TN, Tapley P, Klein R, Glass DJ, Fandl J, Greene LA, Barbacid M, Yancopoulos GD (1993) Similarities and differences in the way the neurotrophins interact with the Trks in neuronal and non-neuronal cells. Neuron 10:1-10.

Jing S, Tapley P, Barbacid M (1992) Nerve growth factor mediates signal transduction through trk homodimer receptors. Neuron 9:10671079 .

Johnson D, Lanahan A, Buck CR, Sehgal A, Morgan C, Mercer E, Bothwell M, Chao M (1986) Expression and structure of the human NGF receptor. Cell 47:545-554.

Johnson EM, Andres RY, Bradshaw RA (1978) Characterization of the retrograde transport of nerve growth factor (NGF) using high specific activity 1251-NGF. Brain Res 150:319-331.

Kaplan DR, Martin-Zanca D, Parada LF (1991) Tyrosine phosphorylation and tyrosine kinase activity of the $t r k$ proto-oncogene product induced by NGF. Nature 350:158-160.

Kaufman DL, Houser CR, Tobin AJ (1991) Two forms of the $\delta$-aminobutyric acid synthetic enzyme glutamate decarboxylase have distinct intraneuronal distributions and cofactor interactions. J Neurochem 56:720-723.

Kimura H, Kuriyama K (1975) A new microassay method for L-glutamic acid decarboxylase (GAD) activity. Jpn J Pharmacol 25:189_ 195.

Klein R, Parada LF, Coulier F, Barbacid M (1989) trk B, a novel tyrosine protein kinase receptor expressed during mouse neural development. EMBO J 8:3701-3709.

Klein R, Conway D, Parada LF, Barbacid M (1990) The $t r k B$ tyrosine kinase gene codes for a second neurogenic receptor that lacks the catalytic kinase domain. Cell 61:647-656.

Klein R, Jing S, Nanduri V, O'Rourke E, Barbacid M (1991a) The trk proto-oncogene encodes a receptor for nerve growth factor. Cell 65: $189-197$

Klein R, Nanduri V, Jing S, Lamballe F, Tapley P, Bryant S, CordonCardo C, Jones KR, Reichardt LF, Barbacid M (1991b) The trkB tyrosine protein kinase is a receptor for brain-derived neurotrophic factor and neurotrophin-3. Cell 66:395-403.

Knüsel B, Michel PP, Schwaber JS, I Iefti $\Gamma$ (1990) Selective and nonselective stimulation of central cholinergic and dopaminergic development in vitro by nerve growth factor, basic fibroblast growth factor, epidermal growth factor, insulin and the insulin-like growth factors I and II. J Neurosci 10:558-570.

Knüsel B, Winslow JW, Rosenthal A, Burton LE, Seid DP, Nikolics K, Hefti $F$ (1991) Promotion of central cholinergic and dopaminergic neuron differentiation by brain-derived neurotrophic factor but not neurotrophin-3. Proc Natl Acad Sci USA 88:961-965.
Lamballe F, Klein R, Barbacid M (1991) trk C, a new member of the trk family of tyrosine protein kinases, is a receptor for neurotrophin3. Cell 66:967-979.

Leibröck J, Lottspeich F, Hohn A, Hofer M, Hengerer B, Masiakowski P, Thoenen H, Barde Y-A (1988) Molecular cloning and expression of brain-derived neurotrophic factor. Nature 341:149-152.

Levi-Montalcini R, Angeletti PU (1968) Nerve growth factor. Physiol Rev 48:534-569.

Lin L-FH, Doherty DH, Lile JD, Bektesh S, Collins F (1993) GDNF: a glial cell line-derived neurotrophic factor for midbrain dopaminergic neurons. Science 260:1130-1132.

Lindsay RM (1988) Nerve growth factors (NGF, BDNF) enhance axonal regeneration but are not required for survival of adult sensory neurons. J Neurosci 8:2394-2405.

Lindsay RM, Thoenen H, Barde Y-A (1985) Placode and neural crestderived sensory neurons are responsive at early developmental stages to brain-derived neurotrophic factor. Dev Biol 112:319-328.

Maisonpierre PC, Belluscio L, Squinto S, Ip NY, Furth ME, Lindsay RM, Yancopoulos GD (1990a) Neurotrophin-3: a neurotrophic factor related to NGF and BDNF. Science 247:1446-1451.

Maisonpierre PC, Belluscio L, Friedman B, Alderson RF, Wiegand SJ, Furth ME, Lindsay RM, Yancopoulos GD (1990b) NT-3, BDNF, and NGF in the developing rat nervous system: parallel as well as reciprocal patterns of expression. Neuron 5:501-509.

Maniatis T, Fritsch EF, Sambrook J (1982) In: Molecular cloning: a laboratory manual. Cold Spring Harbor, NY: Cold Spring Laboratory.

Meakin SO, Shooter EM (1991) Molecular investigations on the highaffinity nerve growth factor receptor. Neuron 6:153-163.

Mercugliano M, Soghomonian JJ, Qin Y, Nguyen HQ, Feldblum S, Erlander MG, Tobin AJ, Chesselet M-F (1992) Comparative distribution of messenger RNAs encoding glutamic acid decarboxylases $\left(M, 65,000\right.$ and $\left.M_{r} 67,000\right)$ in the basal ganglia of the rat. J Comp Neurol 318:245-254

Merlio J, Ernfors P, Jaber M, Persson H (1992) Molecular cloning of rat trkC and distribution of cells expressing messenger RNAs for members of the trk family in the rat central nervous system. Neuroscience 51:513-532.

Moore RY, Bloom FE (1978) Central catecholamine neuron systems: anatomy and physiology of the norepinephrine and epinephrine systems. Neuroscience 2:113-168.

Mugnaini E, Oertel WH (1985) An atlas of the distribution of GABAergic neurons and terminals in the CNS as revealed by GAD immunohistochemistry. In: Handbook of neuroanatomy, Vol 4 (Bjorklund A, Hokfelt T, eds), pp 436-608. Amsterdam: Elsevier.

Nebreda AR, Martin-Zanca D, Kaplan DR, Parada LF, Santos E (1991) Induction by NGF of meiotic maturation of Xenopus oocytes expressing the $t r k$ proto-oncogene product. Science 252:558-563.

Niijima K, Araki M, Ogawa M, Nagatsu I, Sato F, Kimura H, Yoshida M (1990) Enhanced survival of cultured dopamine neurons by treatment with soluble extracts from chemically deafferented striatum of adult rat brain. Brain Res 528:151-154.

Nissbrandt H, Carlsson A (1987) Turnover of dopamine and dopamine metabolites in rat brain: comparison between striatum and substantia nigra. J Neurochem 49:959-967.

Oertel WH, Tappaz ML, Berod A, Mugnaini E (1982) Two-color immunohistochemistry for dopamine and GABA neurons in rat substantia nigra and zona incerta. Brain Res Bull 9:463-474.

O'Malley EK, Black IB, Dreyfus CF (1991) Local support cells promote survival of substantia nigra dopaminergic neurons in culture Exp Neurol 112:40-48.

Radeke MJ, Misko TP, Hsu C, Herzenberg LA, Shooter EM (1987) Gene transfer and molecular cloning of the rat nerve growth factor receptor. Nature 325:593-597.

Refshauge C, Kissinger PT, Dreiling R, Blank L, Freeman R, Adams RN (1974) New high performance liquid chromatographic analysis of brain catecholamines. Life Sci 14:311-322.

Richardson PM, Vergelssa VMK, Riopelle RJ (1986) Distribution of neuronal receptors for nerve growth factor in the rat. J Neurosci $6: 2312-2321$

Rodriguez-Tébar A, Dechant G, Barde Y-A (1990) Binding of brainderived neurotrophic factor to the nerve growth factor receptor. Neuron 4:487-492.

Rosenthal A, Goeddel DV, Nguyen T, Lewis M, Shih A, Laramee GR, Nikolics K, Winslow JW (1990) Primary structure and biological activity of a novel human neurotrophic factor. Neuron 4:767-773.

Schwab ME, Otten U, Agid Y, Thoenen H (1979) Nerve growth factor 
(NGF) in the rat CNS: absence of specific retrograde axonal transport and tyrosine hydroxylase induction in locus coeruleus and substantia nigra. Brain Res 168:473-483.

Seiler M, Schwab ME (1984) Specific retrograde transport of nerve growth factor from the neocortex to nucleus basalis in the rat. Brain Res 300:33-39.

Smith PK, Krohn RI, Hermanson GT, Mallia AK, Gartner FH, Drovenzano MD, Fujimoto EK, Goeke NM, Olson BJ, Klenk DC (1985) Measurement of protein using bicinchoninic acid. Anal Biochem 150: $76-85$.

Soppet D, Escandon E, Maragos J, Middlemas DS, Reid SW, Blair J Burton LE, Stanton BR, Kaplan DR, Hunter T, Nikolics K, Parada LF (1991) The neurotrophic factors brain-derived neurotrophic factor and neurotrophin- 3 are ligands for the trk B tyrosine kinase receptor. Cell 65:895-903.

Spina MB, Squinto SP, Miller J, Lindsay RM, Hyman C (1992) Brainderived neurotrophic factor protects dopamine neurons against 6-hydroxydopamine and $N$-methyl-4-phenylpyridinium ion toxicity: involvement of the glutathione system. J Neurochem 59:99-106.

Squinto SP, Stitt TN, Aldrich TH, Davis S, Bianco SM, Radziejewski C, Glass DJ, Masiakowski P, Furth ME, Valenzuela DM, DiStefano PS, Yancopoulos GD (1991) trk B encodes a functional receptor for brain-derived neurotrophic factor and neurotrophin-3 but not nerve growth factor. Cell 65:885-893.
Stöckel K, Schwab ME, Thoenen H (1975) Specificity of retrograde transport of nerve growth factor (NGF) in sensory neurons: a biochemical and morphological study. Brain Res 89:1-14.

Thoenen H, Barde Y-A (1980) Physiology of nerve growth factor. Physiol Rev 60:1284-1335.

Thoenen H, Bandtlow C, Heumann R (1987) The physiological function of nerve growth factor in the central nervous system: comparison with the periphery. Rev Physiol Biochem Pharmacol 109:145-171.

Tomozawa Y, Appel SH (1986) Soluble striatal extracts enhance development of mesencephalic dopaminergic neurons in vitro. Brain Res 399:111-124.

Valenzuela D, Maisonpierre P, Glass D, Rojas E, Nuñez L, Kong Y, Gies D, Stitt T, Ip N, Yancopoulos G (1993) Alternate forms of rat TrkC with different functional capabilities. Neuron 19:666.

Ventimiglia R, Mather P, Lindsay RM (1993) Brain-derived neurotrophic factor promotes survival and biochemical differentiation of striatal GABA neurons in vitro. Soc Neurosci Abstr 10:963-974.

Wiegand SJ, Anderson K, Alexander C, Criden M, Altar CA, Lindsay RM, DiStefano PS (1992) Receptor binding and axonal transport of 125I-labeled neurotrophins in the basal ganglia and related brain regions. Movement Disord 7:63. 